\title{
The contribution of activated astrocytes to $A \beta$ production: Implications for Alzheimer's disease pathogenesis
}

\author{
Jie Zhao, Tracy O'Connor and Robert Vassar
}

\begin{abstract}
Background: $\beta$-Amyloid (A $\beta$ ) plays a central role in Alzheimer's disease (AD) pathogenesis. Neurons are major sources of $A \beta$ in the brain. However, astrocytes outnumber neurons by at least five-fold. Thus, even a small level of astrocytic $A \beta$ production could make a significant contribution to $A \beta$ burden in AD. Moreover, activated astrocytes may increase A $\beta$ generation. $\beta$-Site APP cleaving enzyme 1 (BACE1) cleavage of amyloid precursor protein (APP) initiates $A \beta$ production. Here, we explored whether pro-inflammatory cytokines or $A \beta 42$ would increase astrocytic levels of BACE1, APP, and $\beta$-secretase processing, implying a feed-forward mechanism of astrocytic A $\beta$ production.

Methods: Mouse primary astrocytes were treated with combinations of LPS, TNF- $\alpha$, IFN- $\gamma$, and IL-1 $\beta$ and analyzed by immunoblot and ELISA for endogenous BACE1, APP, and secreted A 40 levels. Inhibition of JAK and iNOS signaling in TNF- $\alpha+$ IFN- $\gamma$-stimulated astrocytes was also analyzed. In addition, C57BL/6J or Tg2576 mouse astrocytes were treated with oligomeric or fibrillar A 342 and analyzed by immunoblot for levels of BACE1, APP, and APPs $\beta$ sw. Astrocytic BACE1 and APP mRNA levels were measured by TaqMan RT-PCR.

Results: TNF- $\alpha+$ IFN- $\gamma$ stimulation significantly increased levels of astrocytic BACE1, APP, and secreted A 340 . BACE1 and APP elevations were post-transcriptional at early time-points, but became transcriptional with longer TNF- $\alpha$ + IFN- $\gamma$ treatment. Despite a $\sim$-fold increase in astrocytic BACE1 protein level following TNF- $\alpha+$ IFN- $\gamma$ stimulation, BACE1 mRNA level was significantly decreased suggesting a post-transcriptional mechanism. Inhibition of iNOS and JAK did not reduce TNF- $\alpha+$ IFN- $\gamma$-stimulated elevation of astrocytic BACE1, APP, and A $\beta 40$, except that JAK inhibition blocked the APP increase. Finally, oligomeric and fibrillar A 42 dramatically increased levels of astrocytic BACE1, APP, and APPs $\beta$ sw through transcriptional mechanisms, at least in part.

Conclusions: Cytokines including TNF- $\alpha+$ IFN- $\gamma$ increase levels of endogenous BACE1, APP, and A $\beta$ and stimulate amyloidogenic APP processing in astrocytes. Oligomeric and fibrillar A 342 also increase levels of astrocytic BACE1, APP, and $\beta$-secretase processing. Together, our results suggest a cytokine- and A $\beta 42$-driven feed-forward mechanism that promotes astrocytic $A \beta$ production. Given that astrocytes greatly outnumber neurons, activated astrocytes may represent significant sources of $A \beta$ during neuroinflammation in $A D$.
\end{abstract}

Keywords: Aß, APP, Astrocyte, BACE1, $\beta$-secretase, Cytokine, IFN- $\gamma$, Neuroinflammation, oligomer, TNF-a

\section{Background}

The neuropathology of Alzheimer's disease (AD) is characterized by the development of extracellular deposits of senile amyloid plaques that are mainly composed of the $\beta$-amyloid peptide $(A \beta)$. AD pathogenesis is likely to involve elevated cerebral $A \beta$ levels that in turn cause

\footnotetext{
* Correspondence: r-vassar@northwestern.edu

Department of Cell \& Molecular Biology, Northwestern University Feinberg School of Medicine, Chicago, Illinois, 60611, USA
}

neuroinflammation and neurodegeneration, ultimately leading to dementia through a cascade of neurotoxic events [1-5]. Marked by focal activation of microglia and astrocytes in the vicinity of amyloid plaques, AD-associated inflammation has been widely described by pathological examination of brain tissue from $\mathrm{AD}$ patients and transgenic mouse models [3,6-16]. It has therefore received much attention in the analysis of $\mathrm{AD}$ pathological progression [17-19]. The resulting neuroinflammatory
C Biomed Central

() 2011 Zhao et al; licensee BioMed Central Ltd. This is an Open Access article distributed under the terms of the Creative Commons Attribution License (http://creativecommons.org/licenses/by/2.0), which permits unrestricted use, distribution, and reproduction in any medium, provided the original work is properly cited. 
processes usually involve the release from activated glia of a number of potentially neurotoxic molecules, including reactive oxygen species, nitric oxide, and pro-inflammatory chemokines and cytokines such as interleukin- $1 \beta$ (IL-1 $\beta$ ), tumor necrosis factor- $\alpha$ (TNF- $\alpha$ ), and interferon- $\gamma($ IFN- $\gamma)$. Excessive levels of these mediators are apt to induce neuronal damage through a variety of mechanisms in $\mathrm{AD}$ and other neurodegenerative disorders [20]. Although the inflammatory processes in AD have been well studied, the amyloidogenic potential of glial cells under pro-inflammatory conditions and the mechanisms involved have been relatively unexplored.

Neurons are believed to be the major source of $A \beta$ in normal and $\mathrm{AD}$ brains [21,22]. $\mathrm{A} \beta$ is a proteolytic product of amyloid precursor protein (APP) resulting from sequential cleavages by the $\beta$ - and $\gamma$-secretase enzymes [2]. The transmembrane aspartic protease BACE1 ( $\beta$-site APP-cleaving enzyme 1; also known as Asp2 and memapsin 2) has been identified as the $\beta$-secretase and is therefore the key enzyme that initiates $A \beta$ peptide generation [23-27]. Among specific cell populations in the CNS, neurons express higher levels of BACE1 than glial cells like astrocytes, indicating that astrocytes are less likely to be significant generators of $A \beta$ under normal conditions $[23,28]$. However, it should be noted that AD may take decades to develop and progress, and astrocytes outnumber neurons by over five-fold in the brain $[29,30]$. Together, these data suggest the possibility that the generation of astrocyte-derived $A \beta$, even if low on a per-cell basis, could contribute significantly to cerebral $A \beta$ levels and exacerbate amyloid pathology over time in $\mathrm{AD}$.

A limited number of studies to date have investigated the effects of pro-inflammatory cytokine and $A \beta$ stimulation on BACE1 and APP levels and $\beta$-secretase processing of APP in astrocytes. APP levels have been reported to be elevated by certain pro-inflammatory conditions in mouse brain and in human neuroblastoma and nonneuronal cells, as well as in human astrocyte cultures, suggesting the potential for amyloidogenic APP processing associated with pro-inflammatory conditions [31-34]. The synergistic effects of TNF- $\alpha$ and IFN- $\gamma$ on promoting $\mathrm{A} \beta$ production have been demonstrated for cultured cells including astrocytes $[33,35,36]$. In addition, it has been reported that IFN- $\gamma$ alone stimulated BACE1 expression and $\beta$-secretase cleavage in human astrocytoma cells and astrocytes derived from $\mathrm{Tg} 2576$ transgenic mice that overexpress human APP with the Swedish familial AD mutation (APPsw), but its effect on $A \beta$ production was not investigated $[37,38]$. A subsequent study suggested that the IFN- $\gamma$-stimulation activated BACE1 gene transcription via the JAK/STAT signaling pathway in astrocytes [39]. Other studies in APP transgenic mice have provided further support for the involvement of TNF- $\alpha$ and IFN- $\gamma$ in the development of AD-related amyloid pathology and memory dysfunction $[40,41]$. One report showed that TNF- $\alpha$ and IFN $-\gamma$ stimulation increased $A \beta$ production in $\mathrm{Tg} 2576$ transgenic astrocytes [40]. However, no study to date has explored the effects of TNF- $\alpha$ and IFN- $\gamma$ on endogenous wild-type APP, BACE1 and A $\beta$ in astrocytes, which may be more relevant to AD than transgenically overexpressed mutant APP.

Conversely, other studies have shown that $\mathrm{A} \beta$ itself is able to stimulate astrocytes to secrete pro-inflammatory molecules in vitro and in vivo [42-45]. Oligomers of $\mathrm{A} \beta 42$, the 42 amino acid fibrillogenic form of $\mathrm{A} \beta$, disrupt synaptic function and activate astrocytes $[1,2,42,43,46]$. Fibrillar $A \beta 42$, which is a primary component of amyloid plaques, also causes astrocyte activation [43]. Together with the cytokine cycle of neuroinflammation, these results suggest that a feed-forward loop may operate during $\mathrm{AD}$ whereby cytokines stimulate the production and secretion of $A \beta$ in astrocytes, and then astrocytic $A \beta$ in turn promotes further cytokine release and astrocytic $A \beta$ generation $[4,17]$. This is a compelling hypothesis, but direct evidence in support of it has been limited thus far.

Here, to investigate whether activated astrocytes could be significant sources of $\mathrm{A} \beta$ during $\mathrm{AD}$ neuroinflammation and whether an amyloidogenic astrocytic feed-forward mechanism may exist, we treated cultured primary wild-type C57BL/6J or Tg2576 mouse astrocytes with pro-inflammatory cytokine combinations or $A \beta 42$ oligomers and fibrils and measured levels of BACE1, APP, secreted $A \beta 40$, or $A P P s \beta$ sw, the $\beta$-secretase cleavage product. We observed that cytokines, especially combinations containing TNF- $\alpha+$ IFN- $\gamma$, raised the levels of endogenous BACE1 and APP in C57BL/6J astrocytes and promoted the secretion of astrocytic $A \beta 40$. Inhibitor treatments suggested that iNOS signaling was not involved in cytokine-stimulated astrocytic BACE1, APP, and $A \beta 40$ elevations, although JAK signaling appeared to have a role in the endogenous astrocytic APP increase. Similar to the effects of cytokine stimulation, A 442 oligomers and fibrils elevated levels of endogenous BACE1 and APP in C57BL/6J astrocytes, and increased $\beta$-secretase cleavage of APPsw in Tg2576 astrocytes. The astrocytic APP and BACE1 elevations for cytokine or $A \beta 42$ stimulations appeared in some cases to involve combined transcriptional and post-transcriptional mechanisms, depending on the stimulation. Overall, our results support the hypothesis that cytokine- and $A \beta 42-$ stimulated astrocytes could contribute significantly to the total burden of cerebral $A \beta$ in $A D$, potentially through elevated astrocytic $\beta$-secretase processing of APP under neuroinflammatory conditions. Moreover, the similar effects of cytokine or $A \beta 42$ stimulation on 
astrocytic $\beta$-secretase processing suggest a feed-forward mechanism that might promote $A \beta$ generation in astrocytes.

\section{Methods}

Materials and reagents

The bacterial endotoxin LPS purchased from SigmaAldrich (St. Louis, MO) was from Salmonella typhimurium. Stock solutions were prepared with sterile Dulbecco's phosphate-buffered saline (D-PBS) (InvitrogenGibco; Carlsbad, CA) at a concentration of $1 \mathrm{mg} / \mathrm{ml}$. The recombinant murine cytokines TNF- $\alpha$, IL- $1 \beta$, and IFN- $\gamma$ were purchased from R\&D Systems (Minneapolis, $\mathrm{MN}$ ) and reconstituted in sterile $0.1 \%$ bovine serum albumin (BSA; Sigma) in D-PBS at a concentration of $10,5,50 \mu \mathrm{g} / \mathrm{ml}$, respectively. iNOS inhibitor (1400W; Catalog \# ALX-270-073) was procured from Alexis Biochemicals (San Diego, CA); JAK inhibitor (Catalog \# 420099) was obtained from EMD-Calbiochem (San Diego, CA). A $\beta 42$ peptide was purchased from American Peptide (Sunnyvale, CA). Antibodies used for immunoblotting and fluorescence immunocytochemistry are listed in Table 1. The RNeasy Mini Kit from Qiagen (Valencia, CA) was applied for astrocyte RNA isolation and real-time PCR experiments.

\section{Primary astrocyte culture}

The wild-type C57BL/6J and Tg2576 transgenic mice used in this study were purchased from Taconic (Germantown, NY) and colonies of these mice were kept in the Northwestern University Center for Comparative Medicine animal facilities. All animal procedures were in strict accordance with the NIH Guide for the Care and Use of Laboratory Animals and were approved by the Northwestern University Animal Care and Use Committee.

Mouse primary astrocyte cultures were established from cerebral cortices of newborn mouse pups as previously described with some modifications [47]. In brief, postnatal day 1-3 (P1-3) wild-type C57BL/6J mouse brain cortices were harvested in ice-cold D-PBS, and meninges and blood vessels were removed. Tissues were digested in $0.25 \%$ Trypsin containing $0.1 \%$ EDTA (Mediatech; Herndon, VA) at $37^{\circ} \mathrm{C}$ for 15 min, cells were dispersed by gentle trituration, and seeded in Dulbecco's modified Eagle's medium (DMEM; Mediatech) with 10\% fetal bovine serum (FBS; Hyclone; Logan, UT) and 1\% antibiotic solution $(100 \mathrm{U} / \mathrm{ml}$ penicillin- $100 \mu \mathrm{g} / \mathrm{ml}$ streptomycin; Invitrogen-Gibco) in $75 \mathrm{~cm}^{2}$ T-flasks at a density of 1 cortex/flask. Cells were grown in the $37^{\circ} \mathrm{C}$ incubator with $5 \% \mathrm{CO}_{2}$. After 12 days in vitro, the mixed glial cultures became a confluent monolayer, and cells were then detached by trypsinization and re-plated at $1 \times 10^{6}$ cells/well in 6-well plates for pro-inflammatory agent treatments. For $A \beta 42$ treatments, astrocytes were re-plated at $5 \times 10^{5}$ cells/well in 12 -well plates. The purity of astrocytes (>90\%) in the mixed glial cultures with this method was verified using fluorescence immunocytochemistry by staining with anti-glial fibrillary acidic protein (GFAP; astrocyte marker) and antiF4/80 (microglia marker) antibodies (Table 1; data not shown).

\section{LPS and pro-inflammatory cytokine treatments}

LPS was selected as a control in this study due to its well-established features as a potent pro-inflammatory agent. Twenty-four hours after re-plating, mouse primary astrocytes were treated with fresh growth media containing pro-inflammatory agents, either individually or in specific combinations at concentrations described previously $[36,38]$. Single-agent treatments were: LPS (1 $\mu \mathrm{g} / \mathrm{ml})$, TNF- $\alpha$ (30 ng/ml), IL-1 $\beta$ (10 ng/ml), IFN- $\gamma(20$ $\mathrm{ng} / \mathrm{ml})$; combination treatments were: LPS+IFN- $\gamma$, TNF$\alpha+$ IFN- $\gamma$, TNF- $\alpha+$ IL- $1 \beta+$ IFN- $\gamma$ (concentrations same as for single treatments). After 24,48 , or $96 \mathrm{~h}$ of treatment, media were collected, cells were washed two times in ice-cold D-PBS, and then cells were lysed in buffer containing $40 \mathrm{mM}$ Tris- $\mathrm{HCl}, \mathrm{pH} 6.8,2 \%$ sodium dodecyl

Table 1 Primary antibodies used for immunoblotting and immunocytochemistry procedures

\begin{tabular}{|c|c|c|c|c|}
\hline & Host & Clone & Dilution & Source \\
\hline \multicolumn{5}{|l|}{ Monoclonal } \\
\hline Anti-APP A4 & mouse & $22 \mathrm{C} 11$ & $1: 5000$ & Chemicon \\
\hline Anti- $\beta$-actin & mouse & $A C-15$ & $1: 20,000$ & Sigma \\
\hline Anti-F4/80 & rat & Cl:A3-1 & 1:1000 (fluor. ICC ) & Serotec \\
\hline Anti-GFAP & mouse & G-A-5 & $\begin{array}{l}1: 3 \times 10^{9} \\
1: 10^{8} \text { (fluor. ICC }{ }^{a} \text { ) }\end{array}$ & Sigma \\
\hline Anti-IL-1 $\beta$ & mouse & $3 Z D$ & $1: 50,000$ & National Cancer Institute \\
\hline \multicolumn{5}{|l|}{ Polyclonal } \\
\hline Anti-BACE1 (PA1-757) & Rabbit & -—— & $1: 1000$ & Affinity BioReagents \\
\hline Anti-NOS2 (M-19) & Rabbit & - _ — & $1: 1000$ & Santa Cruz Biotechnology \\
\hline
\end{tabular}

${ }^{a}$ Abbreviation: fluor. ICC = fluorescence immunocytochemistry 
sulfate (SDS), $10 \%$ glycerol, $0.02 \%$ sodium azide with freshly added protease inhibitor cocktail (EMD-Calbiochem) for $10 \mathrm{~min}$ on ice followed by brief sonication. Both media and cell lysate samples were stored at $-80^{\circ} \mathrm{C}$ until analysis.

\section{Inhibitor treatments}

Inhibitors were prepared as concentrated stock solutions according to respective manufacture's instructions. The final concentrations of inhibitors in media applied to astrocytes were the following: 1400W (iNOS inhibitor): 1,8 , and $50 \mu \mathrm{M}$; JAK inhibitor: 1,5 , and $20 \mu \mathrm{M}$. Inhibitors were added to culture medium $30 \mathrm{~min}$ prior to stimulation of cells with TNF- $\alpha+$ IFN- $\gamma$ for $96 \mathrm{~h}$. Conditioned medium and cell protein extraction following the treatments were harvested as above.

\section{A 342 preparation and treatment}

Human A $\beta 42$ (American Peptide; Sunnyvale, CA) oligomers and fibrils were prepared as previously described with minor modifications [48]. Briefly, A $\beta 42$ was dissolved in hexafluoroisopropanol (HFIP), lyophilized, dissolved in dimethylsulfoxide (DMSO; Sigma) to a concentration of $5 \mathrm{mM}$, and then diluted to make $100 \mu \mathrm{M}$ stocks either with ice-cold phenol red-free Ham's F12 medium (Biosource; Rockville, MD) for making oligomers, or with $10 \mathrm{mM} \mathrm{HCl}$ at room temperature for making fibrils. Before treating cells, the $100 \mu \mathrm{M} A \beta 42$ stocks, and vehicle controls lacking $A \beta 42$, were incubated for $24 \mathrm{~h}$ on ice for oligomers or at $37^{\circ} \mathrm{C}$ for fibrils. One day prior to $\mathrm{A} \beta 42$ treatments, primary astrocytes were washed twice with D-PBS, and changed into serum-free media. Specifically, G-5 supplement (Invitrogen-GIBCO) was used at $1 \%$ to replace FBS in the growth media for primary astrocytes. Twenty-four hours after serum-free media was applied, $100 \mu \mathrm{M} \mathrm{A} \beta 42$ oligomer and fibril stocks were added to astrocyte cultures at a final concentration of $10 \mu \mathrm{M}$ in the media, and cells were treated for $6,24,48$, or $96 \mathrm{~h}$.

\section{Immunofluorescence microscopy}

Mouse primary astrocytes were plated onto coverslips at $5 \times 10^{5}$ cells/well in 12 -well plates and were then treated with $10 \mu \mathrm{M}$ oligomeric $\mathrm{A} \beta 42$ for $24 \mathrm{~h}$, as described above. Coverslips were then washed two times in DPBS, fixed in $4 \%$ paraformaldehyde/D-PBS, and blocked and permeabilized in $1 \%$ heat inactivated normal goat serum/D-PBS/0.1\% Triton-X100. Astrocytes were stained with anti-APP antibody 22C11 (Chemicon) at 1:200 dilution, washed, and incubated with goat antimouse Alexa 594 antibody (Invitrogen) at 1:500 dilution. Following a final wash and mount with anti-fade, astrocytes were imaged with a fluorescence Nikon Eclipse
E800 microscope and Spot advanced digital camera (Diagnostic Instruments, Sterling Heights, MI).

\section{Immunoblot analysis}

Protein concentrations of the cell lysates were measured using the BCA protein assay kit from Pierce (Rockford, IL). Equal amounts (10-20 $\mu \mathrm{g})$ of protein were separated on 4-12\% NuPAGE Bis-Tris gels in MOPS buffer (Invitrogen) and transferred to Millipore Immobilon-P polyvinylidene difluoride (PVDF) membranes (Fisher Scientific). The blots were cut into strips (based on the size of the protein of interest), blocked in 5\% nonfat dry milk made in Tris-buffered saline with $0.1 \%$ Tween 20 (TBST; Sigma; modified form), $\mathrm{pH} \mathrm{8.0,} \mathrm{for} 1 \mathrm{~h}$ at room temperature (RT) or overnight at $4^{\circ} \mathrm{C}$, and then incubated with primary antibodies recognizing APP (overnight at $4^{\circ} \mathrm{C}$ ), BACE1 ( $2 \mathrm{~h}$ at RT), GFAP (overnight at $4^{\circ} \mathrm{C}$ ), or IL- $1 \beta$ (overnight at $4^{\circ} \mathrm{C}$ ). After washing in TBST, blots were incubated in horseradish peroxidase (HRP)conjugated goat anti-mouse (for APP, 1:5000; for GFAP, $1: 30,000$; for IL-1 $\beta, 1: 5000 ; 1 \mathrm{~h}$ at RT) or goat anti-rabbit (for BACE1, 1:5000; $1 \mathrm{~h}$ at RT) secondary antibodies. Finally, blots were developed using enhanced chemiluminescence (ECL) Plus detection reagents (Amersham Biosceinces; Piscataway, NJ), and digitally imaged using a Kodak Image Station 440C. Some blots were processed in stripping buffer containing $62.5 \mathrm{mM}$ Tris- $\mathrm{HCl}, \mathrm{pH}$ 6.7, $2 \%$ SDS and $115 \mathrm{mM} \beta$-mercaptoethanol at $55^{\circ} \mathrm{C}$ for $30 \mathrm{~min}$, and then re-probed with anti-NOS2 (iNOS) and anti- $\beta$-actin antibodies followed by incubation in HRP-conjugated goat anti-rabbit $(1: 10,000)$ and goat anti-mouse $(1: 20,000)$ secondary antibodies, respectively, as described above. For relative quantification of immunosignals, band intensities recorded with the Kodak Image Station were expressed as percent of vehicle control within each individual experiment.

\section{RNA isolation and real-time PCR}

Astrocytes of C57BL/6J brains were treated with TNF- $\alpha$ or IFN- $\gamma$, either singly or in combination for 6,24 , or 96 $\mathrm{h}$, and their RNA was isolated using the RNeasy Mini kit (Qiagen) and real-time PCR procedures were carried out as described before with some modifications [49]. Briefly, cells were homogenized in guanidine isothiocyanate (GITC)-containing buffer (RLT buffer) supplied in the RNeasy Mini kit with addition of $1 \% \beta$-mercaptoethanol. Following determination of RNA concentration, $1 \mu \mathrm{g}$ of total RNA from each sample was used for first-strand cDNA synthesis using the Invitrogen SuperScript III reverse transcription system. cDNA was amplified using quantitative real-time PCR with Assays-onDemand premixed Taqman primer/probe set for mouse APP and BACE1 mRNAs (Applied Biosystems; Foster City, CA) and analyzed using an Applied Biosystems 
$7900 \mathrm{HT}$ sequence analyzer with the relative quantification method normalized against 18S rRNA (Applied Biosystems). All samples were run in triplicate and averages were determined, and then were expressed as percent of vehicle control within each individual experiment before means and SEMs were acquired.

\section{Mouse A $\beta 40$ ELISA}

Endogenous mouse $A \beta 40$ secreted into the culture media by C57BL/6J primary astrocytes following proinflammatory stimulation was measured by sandwich enzyme-linked immunosorbant assay (ELISA), using reagents from Biosource International (Camarillo, CA). In brief, 96-well NUNC MaxiSorp immunoplates (VWR) were coated with mouse monoclonal anti-mouse $A \beta$ capture antibody (clone 252Q6; Catalog \# AMB0062) diluted at 1:100 in $0.1 \mathrm{M}$ sodium carbonate coating buffer overnight at $4^{\circ} \mathrm{C}$. Plates were then blocked in $200 \mu \mathrm{l} /$ well of $2 \%$ BSA made in D-PBS for $1 \mathrm{~h}$ at RT followed by incubation with native rodent $A \beta 1-40$ peptide (Catalog \# 03-189) standards [dissolved in Dimethyl Sulfoxide (DMSO) (Sigma) at $1000 \mu \mathrm{g} / \mathrm{ml}$ as a stock, then diluted to final concentrations of $0,7.8,15.6,31.3,62.5,125$, 250 , and $500 \mathrm{pg} / \mathrm{ml}$ in growth media] or cell culture media samples, together with detection antibody rabbit anti-A $\beta 40$ (Catalog \# 44-348) diluted in blocking buffer at $1 \mu \mathrm{g} / \mathrm{ml}$ for $2 \mathrm{~h}$ at $\mathrm{RT}$ with rocking. After extensive washing, HRP-conjugated goat anti-rabbit secondary antibody (Catalog \# ALI4404) (1:2000 in blocking buffer) was added to the plates for $1 \mathrm{~h}$ at RT, followed by chromogen for 15-30 min. The reaction was terminated by addition of stop solution immediately before the absorbance was read at $450 \mathrm{~nm}$ on a microplate spectrophotometer (Spectra Max 250; Molecular Devices). Unless otherwise indicated, all reagents above were added at $100 \mu \mathrm{l} /$ well in each step, and were obtained from a human A $\beta 40$ ELISA kit (Biosource International, Catalog \# KHB3481). A $\beta 40$ levels in the media were normalized to total protein in the respective cell lysates and expressed as pg/mg total protein or percent of vehicle control within each individual experiment.

\section{Statistical analysis}

Relative quantification of APP and BACE1 immunoblot bands was performed using Kodak 1D 3.6 image analysis software. At least three independent experiments using C57BL/6J or Tg2576 primary astrocyte cultures pooled from $\sim 1-3$ cortices for each experiment were analyzed. Statistical significance was determined using two-tailed $t$-test (two samples assuming equal variances) with Microsoft Excel. The data are presented as the mean \pm standard error of the mean (SEM), and $\mathrm{p}<0.05$ was considered significant.

\section{Results}

Pro-inflammatory cytokine combinations increase astrocytic BACE1, APP, and A $\beta$

To investigate whether activated astrocytes increase amyloidogenic APP processing under pro-inflammatory conditions, we treated primary astrocytes cultured from neonatal $\mathrm{C} 57 \mathrm{BL} / 6 \mathrm{~J}$ mouse pups with pro-inflammatory agents LPS, TNF- $\alpha$, IL- $1 \beta$, and IFN- $\gamma$, both individually and in the combinations LPS + IFN $-\gamma$, TNF- $\alpha+$ IFN $-\gamma$, TNF- $\alpha+$ IL- $1 \beta+$ IFN $-\gamma$. Numerous studies have reported that these pro-inflammatory cytokines are elevated in AD brain [reviewed in $[3,4,17,20]]$. In addition, we used LPS as a control, since it has been well studied as a stimulus that strongly activates astrocytes both in vitro and in vivo. After astrocyte cultures were treated for 24, 48, and 96 h, cell lysates were prepared for immunoblot analysis of BACE1, APP, and activation markers iNOS and pro-IL-1 $\beta$, and conditioned media was harvested for mouse A $\beta 40$ measurement.

The anti-APP antibody 22C11 labeled both mature $(130 \mathrm{kDa})$ and immature $(110 \mathrm{kDa})$ glycosylated forms of full-length APP (Figure 1A-C), and showed that endogenous APP levels in astrocytes appeared increasingly higher in a time-dependent manner following stimulation with all tested individual pro-inflammatory agents when compared to controls, with the exception of IL-1 $\beta$. The pro-inflammatory cytokine combinations TNF- $\alpha+$ IFN $-\gamma$ and TNF- $\alpha+$ IFN $-\gamma+$ IL $-1 \beta$ produced robust elevations of astrocytic APP levels, reaching $\sim 150-350 \%$ of vehicle controls for all time points. In vehicle-treated cells, basal levels of the $\sim 130 \mathrm{kD}$ mature APP were consistently lower than those of the $\sim 110 \mathrm{kD}$ immature form at all time points. Interestingly, although the cytokine combinations increased both mature and immature APP forms, the magnitudes of the elevations tended to be larger for mature than immature APP (Figure 1A). Together these results suggested that cytokine combination stimulation may enlarge the pool of mature APP substrate for subsequent amyloidogenic processing by BACE1 in astrocytes.

To determine whether the cytokine-stimulated elevation in astrocytic APP protein level could have been the result of increased APP gene transcription, we prepared stimulated primary astrocyte cultures as described above and measured APP mRNA levels by real-time TaqMan quantitative RT-PCR (Figure 1D). Cytokine stimulation did not significantly alter astrocytic APP mRNA levels relative to those of vehicle controls, with the exception that APP mRNA levels in astrocytes treated for $96 \mathrm{~h}$ with TNF- $\alpha+\mathrm{IFN}-\gamma$ were elevated to $\sim 150 \%$ of control values. These data suggested that a significant proportion of the early cytokine-stimulated increases in APP level could be the 


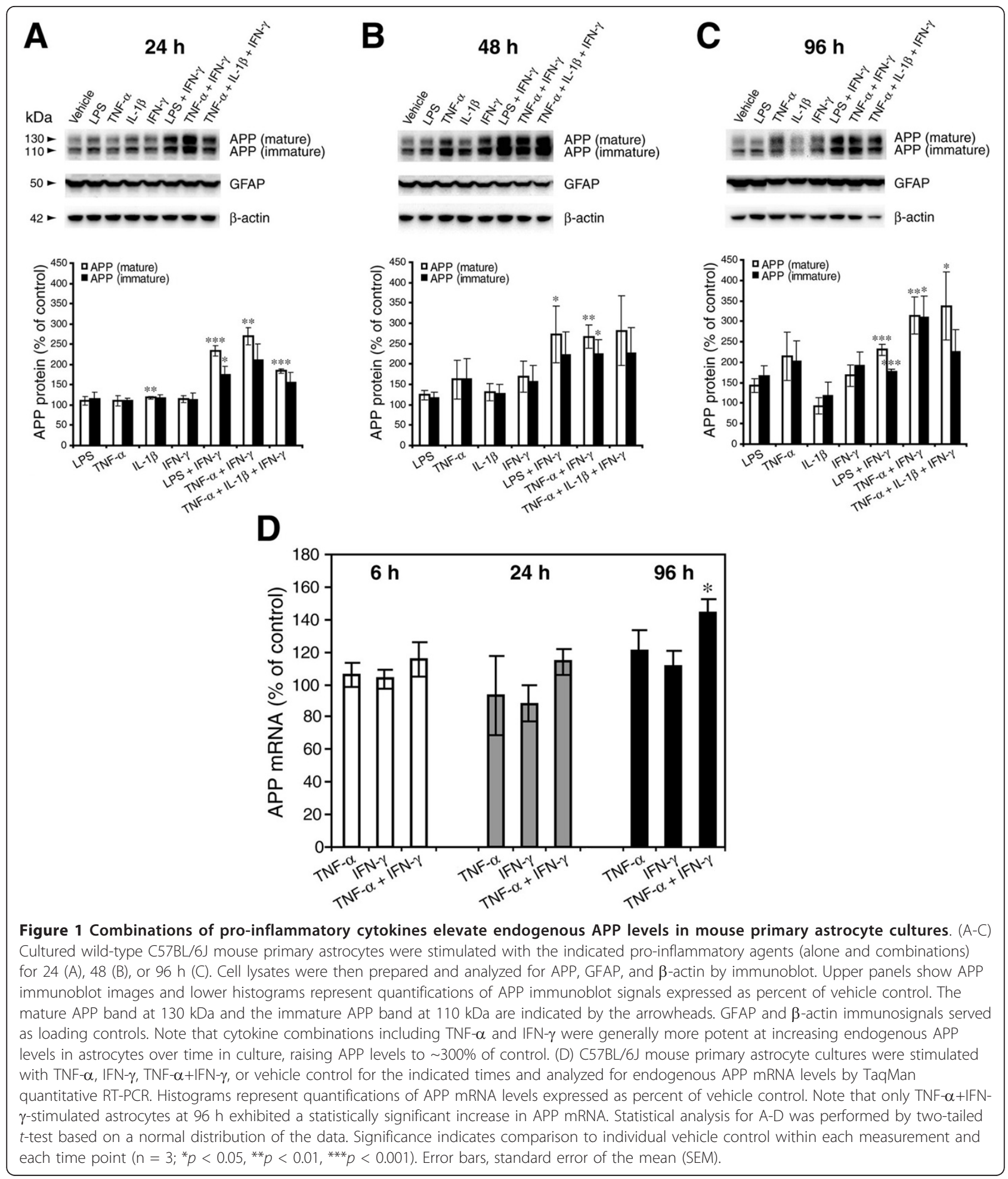

result of a post-transcriptional mechanism. However, increased APP gene transcription or longer APP mRNA half-life might also contribute to the cytokineinduced APP elevation, especially for longer stimulation times with cytokine combinations.
Since BACE1 cleavage of APP initiates A $\beta$ generation, we also measured endogenous BACE1 levels in the same primary astrocytes that were stimulated by the pro-inflammatory agents above. By using lysates of primary astrocytes from $B A C E 1^{-1-}$ mice as negative 
controls in immunoblots (Figure 2A, lanes 9), we clearly demonstrated that un-stimulated astrocytes express low but readily detectable levels of mature BACE1 $(\sim 70$ $\mathrm{kDa}$ ) [50]. Following $24 \mathrm{~h}$ of stimulation, none of the treatments resulted in notable changes in BACE1 level with the exception of LPS alone, which unexpectedly reduced BACE1 levels by a slight amount (Figure 2B), although this effect was transient. Treatments with individual cytokines did not significantly alter BACE1 levels at any time point. Importantly, however, cytokine combinations caused moderate $(\sim 200 \%)$ and strong ( 400$600 \%)$ BACE1 elevations at $48 \mathrm{~h}$ and $96 \mathrm{~h}$, respectively, as compared to vehicle. This dramatic rise in BACE1 level with cytokine combinations suggested that proinflammatory conditions in AD could elevate astrocytic BACE1 and potentially increase amyloidogenic APP processing in astrocytes.

We then investigated whether the cytokine-stimulated increase in astrocytic BACE1 protein level was potentially the result of enhanced BACE1 gene expression. Primary astrocyte cultures treated as above were prepared for TaqMan quantitative RT-PCR to measure BACE1 mRNA levels (Figure 2C). Stimulation with the individual cytokines TNF- $\alpha$ or IFN- $\gamma$ did not produce significant alterations of astrocytic BACE1 mRNA levels. In contrast, the cytokine combination TNF- $\alpha+$ IFN- $\gamma$ unexpectedly caused a $\sim 20-30 \%$ reduction in BACE1 mRNA level in astrocytes (Figure 2C). Thus, despite a large ( 4-fold) increase in BACE1 protein level by $96 \mathrm{~h}$ of TNF- $\alpha+$ IFN- $\gamma$ stimulation, BACE1 mRNA levels were significantly decreased, strongly suggesting that a posttranscriptional mechanism was responsible for the cytokine-stimulated rise in astrocytic BACE1.

Thus far, our results indicated that cytokine combinations could markedly increase levels of endogenous APP and BACE1 in astrocytes. We next sought to determine whether the cytokine-stimulated APP and BACE1 increases would correlate with greater astrocytic $A \beta$ production. Toward this end, we collected conditioned media (CM) from the cytokine-stimulated astrocytes described above and measured endogenous secreted mouse $A \beta 40$ in CM by sandwich ELISA. It is of note that pathogenic $A \beta 42$ is generated in proportion to $A \beta 40$, yet $A \beta 40$ levels are higher for robust quantification. Thus, changes in $A \beta 40$ level faithfully reflect alterations of $A \beta 42$ level.

As expected, endogenous astrocytic A $\beta 40$ levels increased in $\mathrm{CM}$ from $24 \mathrm{~h}$ to $96 \mathrm{~h}$ irrespective of treatment (Figure 3A). However, the accumulation rates and the absolute values of secreted $A \beta 40$ varied depending on the treatment. Stimulations with LPS, TNF- $\alpha$, TNF$\alpha+$ IFN $-\gamma$, and TNF- $\alpha+$ IL- $1 \beta+$ IFN- $\gamma$ all caused secreted A $\beta 40$ levels to increase to $\sim 120-140 \%$ of vehicle control, but only after $96 \mathrm{~h}$ of treatment (Figure 3B). IL-1 $\beta$

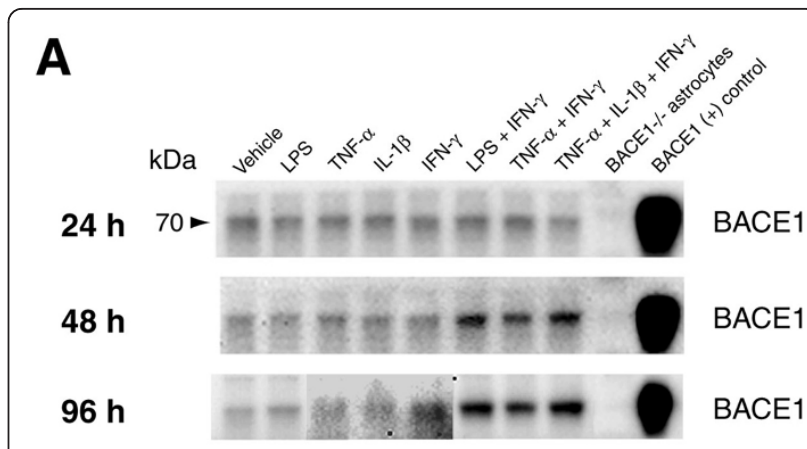

B

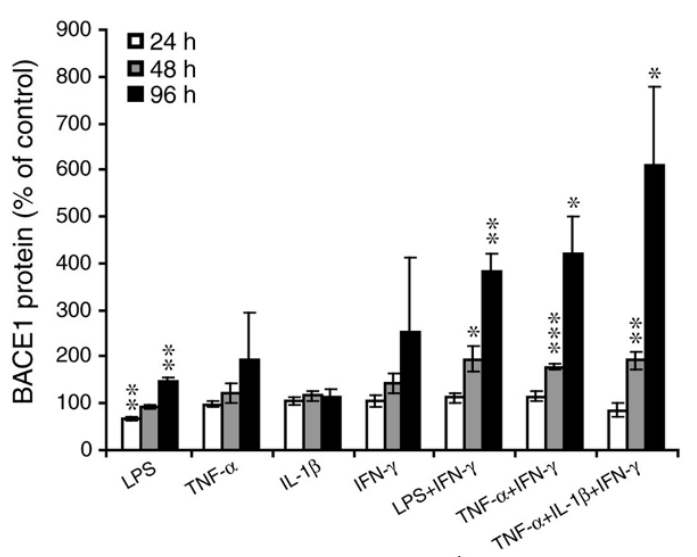

C

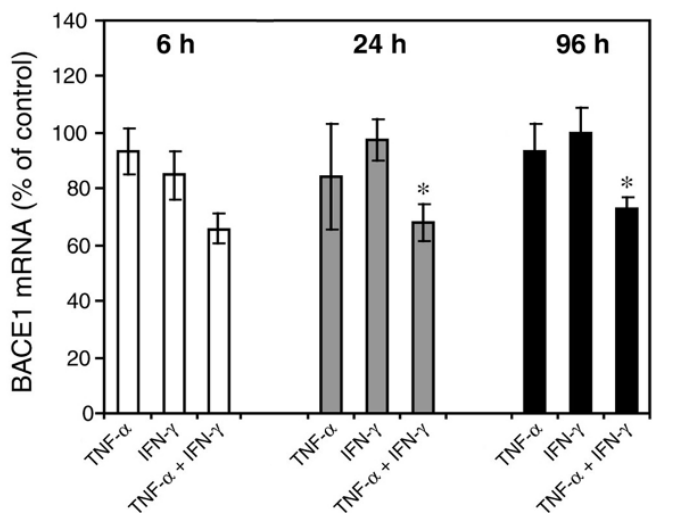

Figure 2 Combinations of pro-inflammatory cytokines elevate endogenous BACE1 levels in mouse primary astrocyte cultures. (A, B) Cell lysates of cytokine-stimulated mouse primary astrocytes analyzed in Fig. 1A-C were analyzed for BACE1 by immunoblot. (A) BACE1 immunoblot images. The mature BACE1 band at $70 \mathrm{kDa}$ is indicated by the arrowhead. Pro-inflammatory agents (alone and combinations) and stimulation times are indicated. Cell lysate from un-stimulated $\mathrm{BACE}^{-1-}$ primary astrocytes was used as a negative control, while cell lysate from a stable BACE1-overexpressing HEK293 cell line was used as a positive control. GFAP and $\beta$-actin immunosignals were loading controls as in Fig 1A-C. (B) Histograms represent quantifications of BACE1 immunoblot signals in (A) expressed as percent of vehicle control. Note that cytokine combinations including TNF- $\alpha$ and IFN- $\gamma$ were generally more potent at increasing endogenous BACE1 levels in astrocytes over time in culture, raising BACE1 levels to $~ 600 \%$ of control. (C) mRNAs prepared from cytokine-stimulated primary astrocytes in Fig 1D were analyzed for endogenous BACE1 mRNA levels by TaqMan 
quantitative RT-PCR. Histograms represent quantifications of BACE1 mRNA levels expressed as percent of vehicle control. Note that astrocytic BACE1 mRNA levels were significantly reduced by TNF- $\alpha$ + IFN- $\gamma$ stimulation (C), even though BACE1 protein levels were increased several fold in similarly treated astrocytes (B). Statistical analysis was the same as described in Fig. 1. Significance indicates comparison to individual vehicle control within each measurement and each time point $\left(n=2-3 ;{ }^{*} p<0.05,{ }^{* *} p<0.01,{ }^{* * *} p<0.001\right)$. Error bars, SEM.

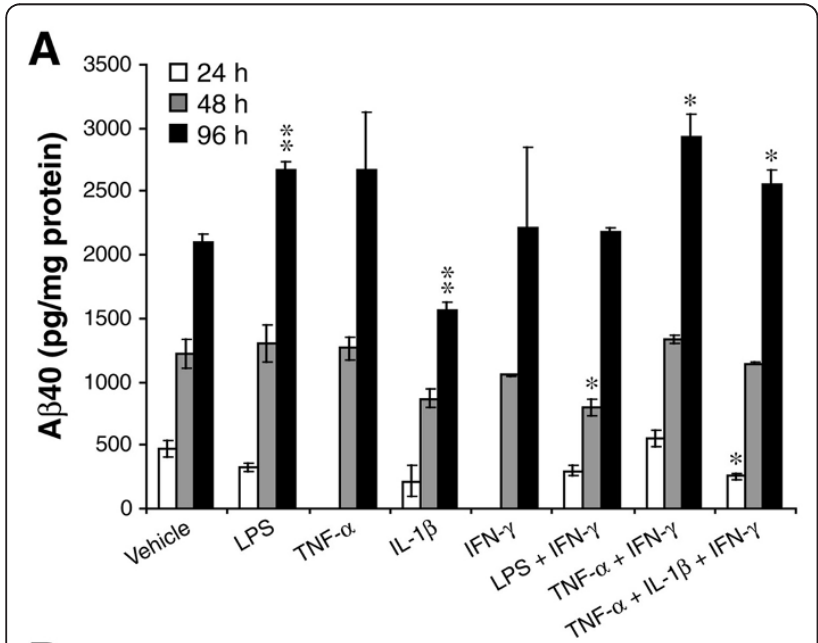

B

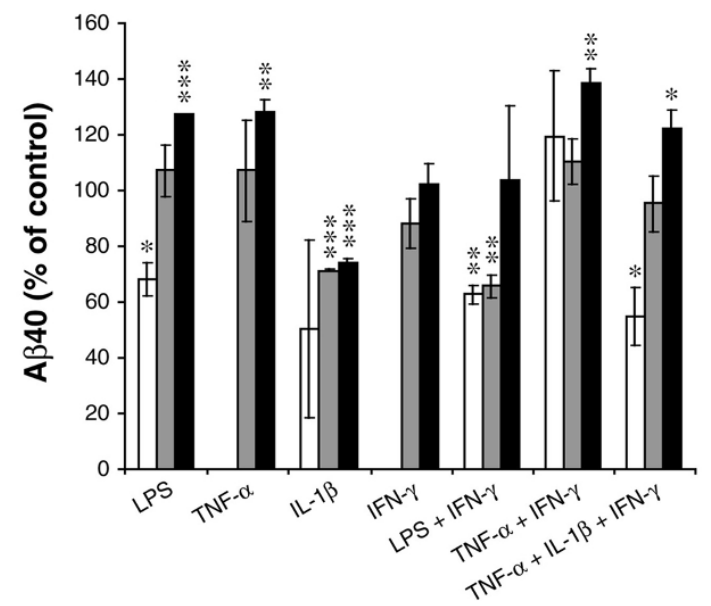

Figure 3 Combinations of pro-inflammatory cytokines elevate endogenous secreted $A \beta 40$ levels in conditioned media from mouse primary astrocyte cultures. Conditioned media (CM) of cytokine-stimulated mouse primary astrocytes analyzed in Fig. 1A-C and Fig. 2A, B were harvested after 24, 48, or $96 \mathrm{~h}$ of proinflammatory agent (individual and combinations) stimulation and analyzed for endogenous mouse A 40 levels by sandwich ELISA. The amount of A $\beta 40$ in $C M$ was expressed as $\mathrm{pg} / \mathrm{mg}$ total protein in the cell lysate (A) or as percent of vehicle control (B). Note that TNF- $\alpha+$ IFN- $\gamma$ stimulation was overall more potent at increasing astrocytic secreted $A \beta 40$ levels, while IL- $1 \beta$ reduced $A \beta 40$ levels at all time points.

Statistical analysis was the same as described in Fig. 1. Significance indicates comparison to individual vehicle control within each time point $\left(\mathrm{n}=3 ;{ }^{*} p<0.05,{ }^{* *} p<0.01\right)$. Error bars, SEM. alone, on the other hand, resulted in decreased levels of secreted $A \beta 40$ at all time points. $A \beta 40$ levels were also reduced by LPS at $24 \mathrm{~h}, \mathrm{LPS}+\mathrm{IFN}-\gamma$ at $24 \mathrm{~h}$ and $48 \mathrm{~h}$, and TNF- $\alpha+$ IL- $1 \beta+$ IFN- $\gamma$ at $24 \mathrm{~h}$. Thus, treatments that included IL-1 $\beta$, either added exogenously or induced endogenously (i.e., by LPS treatment), caused a decrease in A $\beta 40$ level in CM from astrocytes at early (LPS, LPS + IFN- $\gamma$, TNF- $\alpha+$ IL- $1 \beta+$ IFN- $\gamma$ ) or all (IL-1 $\beta$ ) time points. Nevertheless, prolonged stimulation for $96 \mathrm{~h}$ with proinflammatory cytokine combinations resulted in elevated levels of endogenous secreted astrocytic A 440 .

Next, we sought to gain initial insights into potential signaling pathways that might raise levels of endogenous APP, BACE1, and A $\beta$ in astrocytes. Stimulation with TNF- $\alpha+$ IFN $-\gamma$ was used because this combination robustly elevated astrocytic APP, BACE1, and secreted $A \beta$. We first investigated the JAK pathway (Figure 4), which has been implicated in IFN- $\gamma$ receptor signaling. Mouse primary astrocytes cultures were pre-treated for 30 min. with $0,1,5$, or $20 \mu \mathrm{M}$ JAK Inhibitor (JAK-I) followed by exposure to TNF- $\alpha+$ IFN- $\gamma$ in the continued presence of inhibitor. After $96 \mathrm{~h}$ of stimulation, cell lysates and CMs were harvested for APP and BACE1 immunoblot (Figure 4A-C) and A $\beta 40$ ELISA analyses (Figure 4D), respectively. JAK-I reduced the TNF- $\alpha$ + IFN- $\gamma$-stimulated increase in astrocytic APP level in a dose-dependent manner (Figure 4A, B), but it did not block the elevations in astrocytic BACE1 (Figure 4A, C) or secreted $A \beta 40$ (Figure 4D). Unexpectedly, JAK-I treatment with $1 \mu \mathrm{M}$ and $5 \mu \mathrm{M}$ appeared to elevate secreted $A \beta 40$ and BACE1 levels above $0 \mu \mathrm{M}$ JAK-I, respectively, but these increases were not significant. Although it is unclear why JAK-I elevated astrocytic $\mathrm{A} \beta 40$ and BACE1 at certain concentrations but not others, it is important to emphasize that JAK inhibition did not prevent the TNF- $\alpha+$ IFN- $\gamma$-stimulated increase in BACE1 level, suggesting that JAK signaling may play a synergistic but not essential role in the TNF- $\alpha+$ IFN- $\gamma$ stimulated BACE1 elevation. Given that JAK-I reduced the TNF- $\alpha+$ IFN- $\gamma$-stimulated increase in astrocytic APP, it is not completely clear why secreted $A \beta 40$ levels were also not reduced by JAK inhibition. Secreted $A \beta 40$ levels appeared slow to change in response to TNF- $\alpha+$ IFN- $\gamma$ stimulation (Figure 3), so we speculate that secreted $A \beta 40$ could have become significantly reduced with JAK-I treatment times longer than $96 \mathrm{~h}$. This is supported by an observed downward trend in secreted Aß40 with higher JAK-I concentrations (Figure 4D). Regardless, our JAK-I results overall indicate that JAK signaling, at least in part, may play a role in elevating astrocytic APP levels and this might contribute to secreted $A \beta$, although JAK signaling does not appear to contribute to an essential degree to BACE1 levels in astrocytes. 


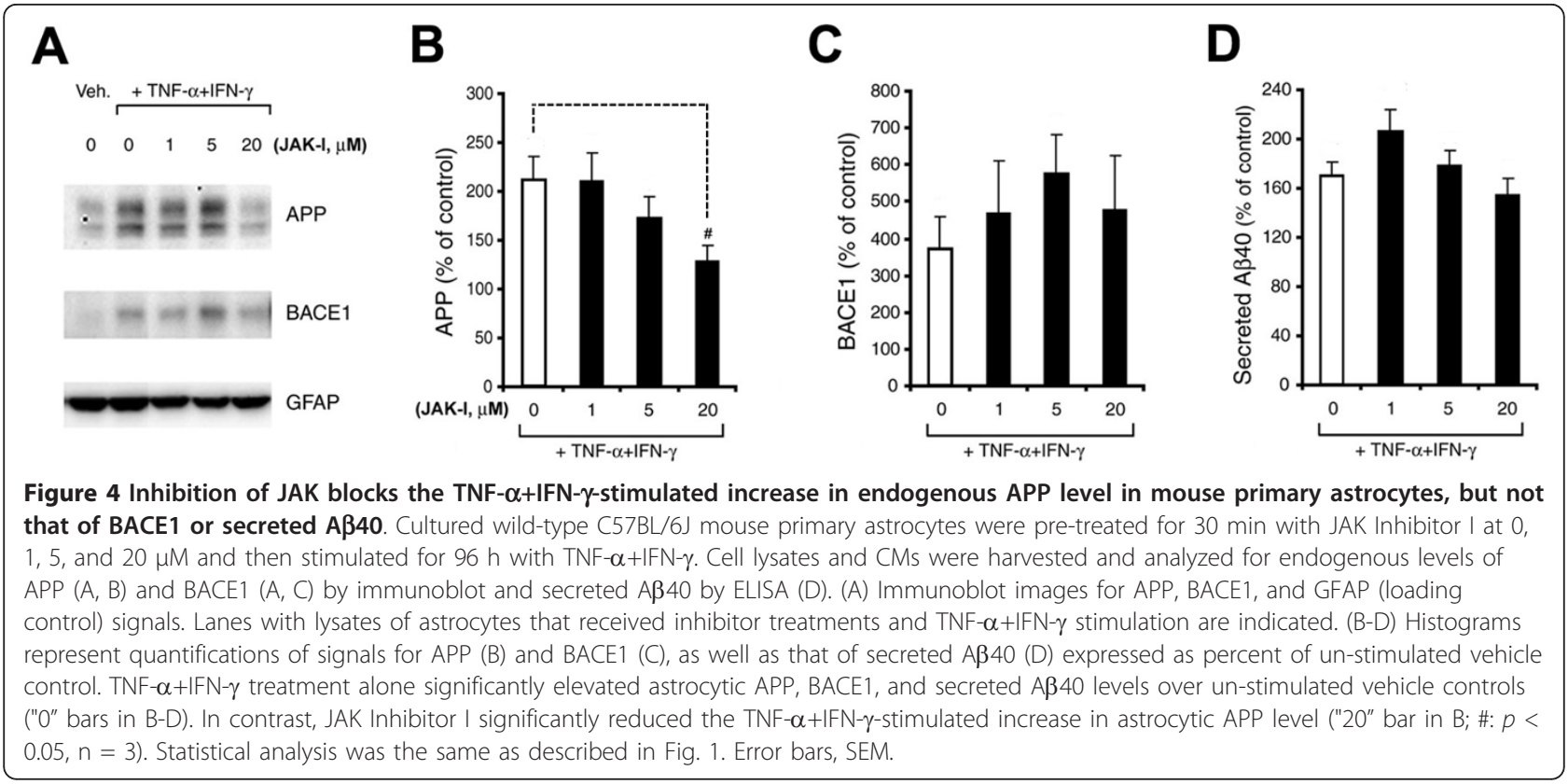

We also investigated signaling through iNOS (NOS2), an inflammatory mediator induced by cytokine stimulation, to explore its potential involvement in amyloidogenic APP processing in astrocytes (Figure 5). Cell lysates from stimulated astrocytes were analyzed by immunoblot to determine iNOS levels. Paralleling the previously observed increases in endogenous APP, BACE1, and A $\beta 40$ levels, iNOS levels were dramatically induced by pro-inflammatory agent combinations at all time points in stimulated astrocytes (Figure 5A). With the exception of the bacterial endotoxin LPS, no singleagent treatment induced appreciable iNOS expression in these cells. These results demonstrated that the elevations of endogenous APP, BACE1, and A $\beta 40$ correlated well with the induction of iNOS in cytokine-stimulated astrocytes.

To determine whether iNOS played a role in the elevation of astrocytic APP, BACE1, and A 440 levels, we pre-treated primary astrocytes cultures with the iNOS inhibitor $1400 \mathrm{~W}$ for $30 \mathrm{~min}$ followed by stimulation with TNF- $\alpha+$ IFN- $\gamma$ for 96 h (Figure 5B-G). As expected, $1400 \mathrm{~W}$ pre-treatment strongly inhibited iNOS activity as demonstrated by dose-dependent suppression of astrocytic nitrite production (Figure $5 \mathrm{C}$ ) without affecting iNOS protein levels (Figure 5B). Immunoblot analysis of cell lysates revealed that the TNF- $\alpha+$ IFN- $\gamma-$ stimulated rise in astrocytic APP and BACE1 was not significantly blocked by iNOS inhibition (Figure 5D-F). However, ELISAs of CMs showed that iNOS inhibition slightly blunted the increase in secreted $A \beta 40$ levels to $\sim 90 \%$ of control values (Figure $5 \mathrm{G}$ ), but this effect was not statistically significant. These results suggested that
iNOS signaling might make a small contribution to cytokine-stimulated increases in astrocytic secreted $A \beta$, but it may do so via a mechanism that is independent of effects on APP and BACE1 expression.

\section{$A \beta 42$ increases astrocytic BACE1, APP, and $\beta$-secretase processing}

It has been posited that AD may involve a "vicious cycle" that becomes self-perpetuating once it is started $[3,51]$. However, direct evidence for this hypothesis has been difficult to obtain. Given that we observed that $A \beta$ secretion was increased in cytokine-stimulated astrocytes, and that astrocytic cytokine release was induced by $A \beta$, we investigated the possibility of an astrocytic vicious cycle involving an $A \beta$-stimulated feed-forward loop $[42,44]$. Specifically, we sought to determine whether oligomers and fibrils of $A \beta 42$, the putative pathogenic agent in AD, could elevate endogenous APP, BACE1, and $\beta$-secretase cleavage of APP in astrocytes. If so, astrocytes might represent a significant source of $A \beta$ production in $\mathrm{AD}$, and understanding the associated mechanism(s) could potentially identify novel astrocytespecific $A \beta$-lowering therapeutic strategies.

To gain insight into these questions, we cultured primary astrocytes from the brains of neonatal C57BL/6J or Tg2576 mouse pups and then treated astrocyte cultures with either oligomeric or fibrillar $A \beta 42$ prepared as previously described [48]. Following treatment, cell lysates were harvested and analyzed for levels of endogenous APP and BACE1 protein and mRNA, and APPs $\beta$, the BACE1-cleaved APP ectodomain fragment. For C57BL/6J wild-type primary astrocytes, APP 


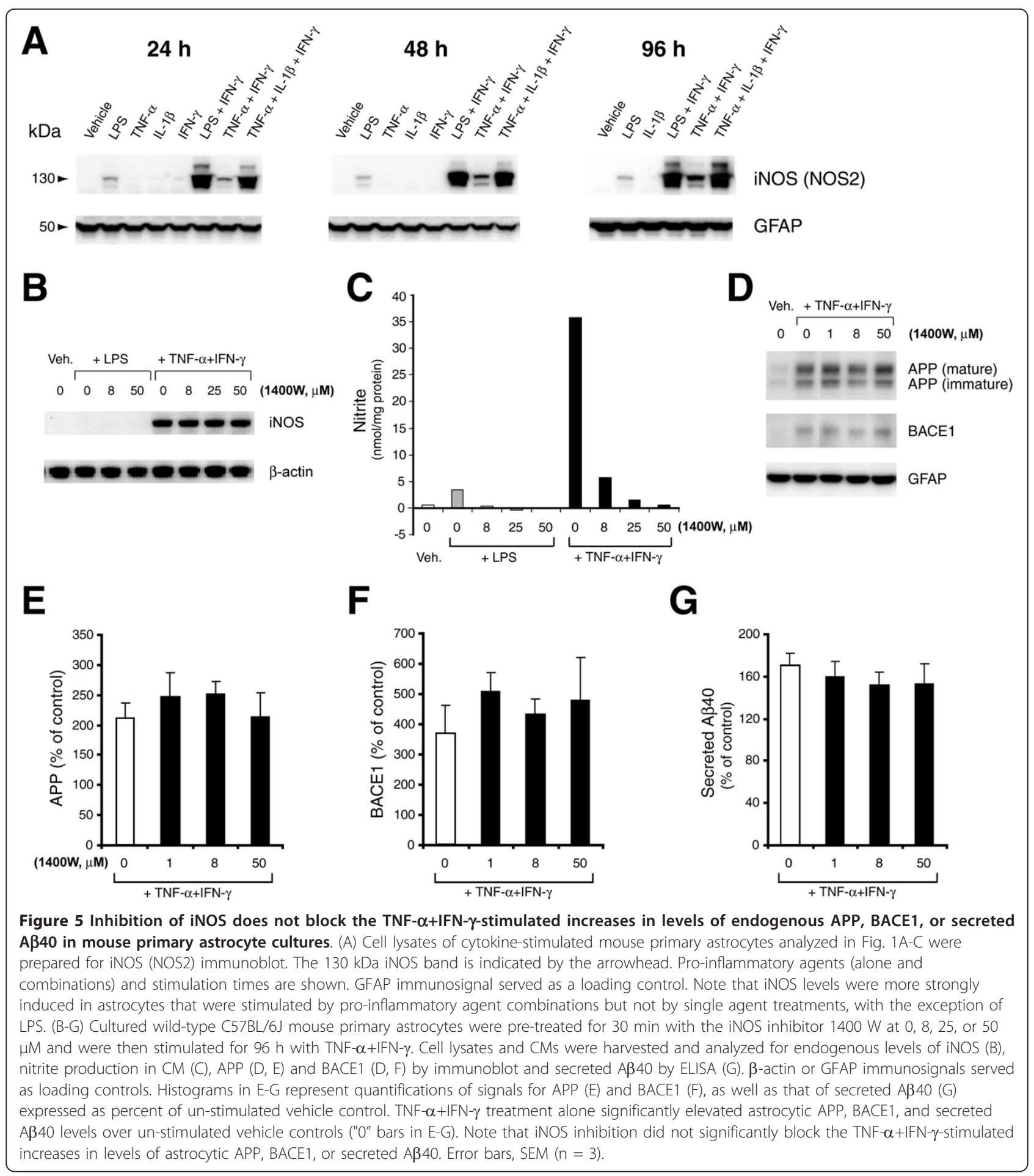

immunoblots revealed that both $A \beta 42$ oligomers and fibrils stimulated a dramatic $400-500 \%$ rise in endogenous APP protein level after $24 \mathrm{~h}$ of $\mathrm{A} \beta 42$ treatment, as compared to oligomeric or fibrillar vehicle controls (Figure $6 \mathrm{~A}, \mathrm{~B})$. This A $\beta 42$-stimulated APP increase remained elevated at $48 \mathrm{~h}$ of $\mathrm{A} \beta 42$ treatment, but APP levels returned to vehicle control levels by $96 \mathrm{~h}$ of treatment (Figure 6A, B). Immunofluorescence microscopy with anti-APP antibody $22 \mathrm{C} 11$ confirmed this robust increase in astrocytic APP level following $24 \mathrm{~h}$ of oligomeric $A \beta 42$ treatment (Figure $6 \mathrm{C}$ ). These results suggested that $A \beta 42$, irrespective of its aggregation state, 


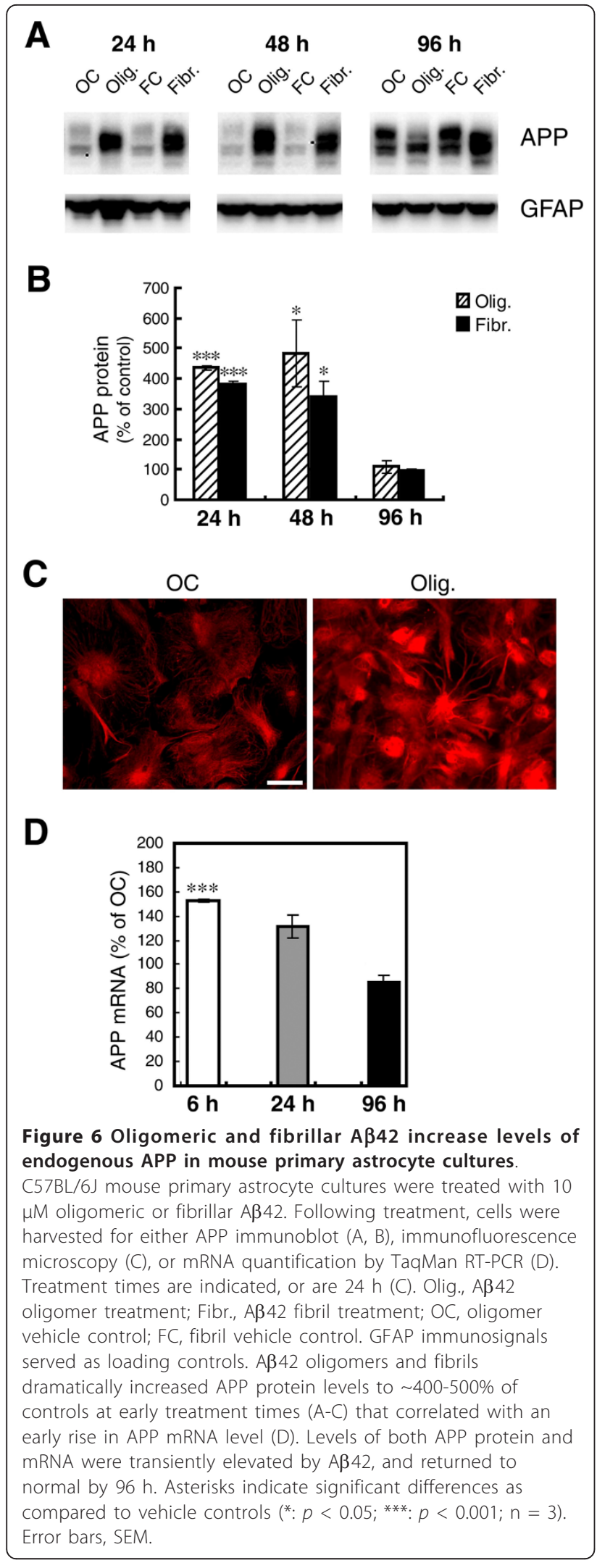

was capable of strongly inducing the expression of endogenous astrocytic APP, at least up to $48 \mathrm{~h}$ of exposure under the culture conditions that we tested.

To determine whether the A $\beta 42$-stimulated astrocytic APP elevation was potentially the result of a transcriptional mechanism, we grew C57BL/6J primary astrocyte cultures, treated them with $\mathrm{A} \beta 42$ and then isolated mRNA and measured APP mRNA levels with TaqMan quantitative RT-PCR (Figure 6D). Since both oligomeric and fibrillar A $\beta 42$ caused similar increases of APP level in astrocytes, we focused on $A \beta 42$ oligomer-treated astrocytes because the mechanisms of APP elevation for both forms of $A \beta 42$ seemed likely to be the same. In addition, mounting evidence suggests that oligomeric forms of $A \beta$ may be more toxic than the fibrillar $A \beta$ found in amyloid plaques, and therefore the former is of considerable therapeutic interest. We observed a rapid, highly significant $\sim 160 \%$ increase in APP mRNA level following only $6 \mathrm{~h}$ of oligomeric $\mathrm{A} \beta 42$ treatment, compared to vehicle control (Figure 6D). By $24 \mathrm{~h}$ of treatment, APP mRNA levels were returning to normal, and by $96 \mathrm{~h}$ oligomer- and vehicle-treated astrocytic APP mRNA levels were the same (Figure 6D). These results demonstrated that the A $\beta 42$-stimulated astrocytic APP elevation was the result of either elevated APP gene transcription or increased APP mRNA stability.

Next, we sought to determine whether $A \beta 42$ treatment could increase endogenous astrocytic BACE1 protein levels. Cell lysates isolated from the oligomeric and fibrillar A $\beta 42$-treated C57BL/6J primary astrocytes used for APP immunoblots (Figure 6A) were analyzed by immunoblot for BACE1 levels (Figure 7A). In contrast to the APP immunoblot results, neither oligomeric nor fibrillar A 342 treatment caused a significant increase in BACE1 level after 24 or 48 hours of stimulation, although a slight upward trend was observed at $48 \mathrm{~h}$ compared to controls (Figure 7B). However, a strong $\sim 300 \%$ increase in BACE1 level was apparent after $96 \mathrm{~h}$ of treatment with $A \beta 42$ oligomers and fibrils. While the fibrillar A 342 -induced astrocytic BACE1 elevation was robust ( $<<0.01$ ), the oligomer-induced BACE1 increase did not reach statistical significance because of high immunoblot signal variability (Figure 7B). However, BACE1 mRNA levels were significantly elevated by oligomer treatment (Figure 7C), suggesting that the BACE1 protein increase was likely real. These results suggested that $A \beta 42$ could increase levels of endogenous $\mathrm{BACE} 1$ in astrocytes regardless of $\mathrm{A} \beta 42$ aggregation state.

To determine whether the A $\beta 42$-stimulated increase of astrocytic BACE1 was possibly the result of a transcriptional mechanism, we performed BACE1 TaqMan 
RT-PCR on mRNA isolated from the oligomeric A $\beta 42-$ treated primary astrocytes used for the APP mRNA measurements described above. A $\beta 42$ oligomers caused a significant increase in the level of astrocytic BACE1 mRNA as early as $6 \mathrm{~h}$ of treatment, an effect that persisted for at least $96 \mathrm{~h}$ (Figure $7 \mathrm{C}$ ). Although relatively

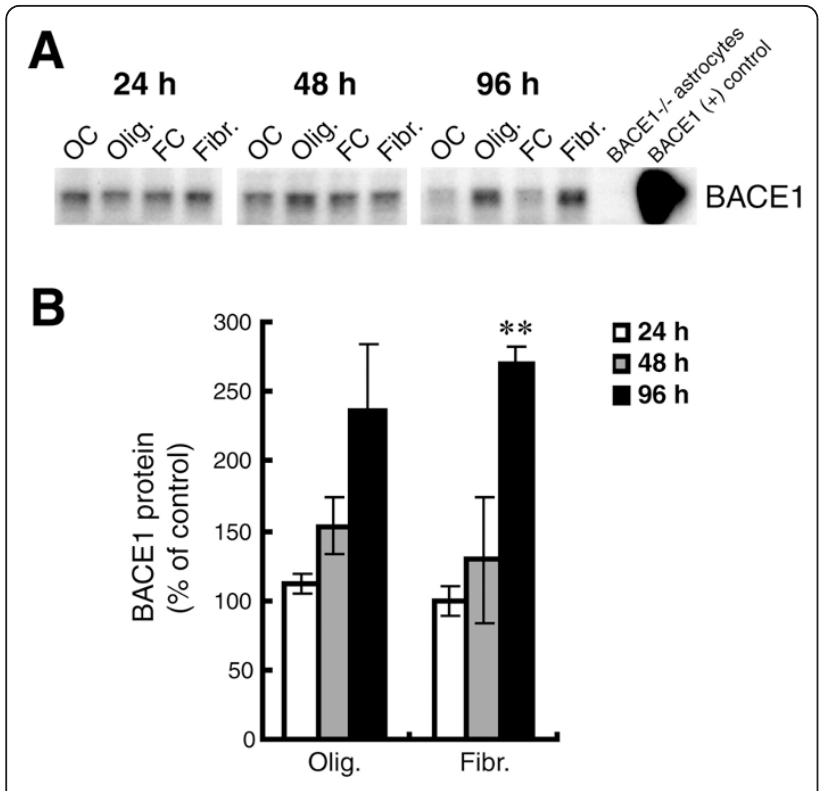

C

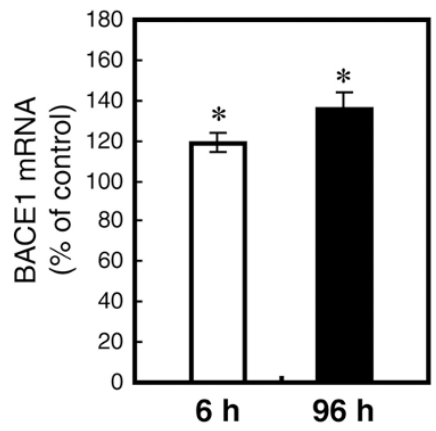

Figure 7 Oligomeric and fibrillar $A \beta 42$ increase levels of endogenous BACE1 in mouse primary astrocyte cultures. Lysates of C57BL/6J mouse primary astrocyte cultures treated with $10 \mu \mathrm{M}$ oligomeric or fibrillar A $\beta 42$ from Fig. 6 were prepared for BACE1 immunoblot (A, B) or mRNA quantification by TaqMan RTPCR (C). Treatment times are indicated. Olig., A $\beta 42$ oligomer treatment; Fibr., A 342 fibril treatment; OC, oligomer vehicle control; FC, fibril vehicle control. Cell lysate from un-treated BACE ${ }^{-1-}$ primary astrocytes was used as a negative control, while cell lysate from a stable BACE1-overexpressing HEK-293 cell line was used as a positive control. GFAP immunosignals were loading controls as in Fig. 6A. A 42 oligomers and fibrils elevated BACE1 protein levels at $48 \mathrm{~h}$ and $96 \mathrm{~h}$ of treatment (A, B). BACE1 levels peaked at nearly $300 \%$ of control at $96 \mathrm{~h}$ that correlated with a rise in BACE1 mRNA level (C). Unlike APP, levels of both BACE1 protein and mRNA did not return to normal but remained elevated at $96 \mathrm{~h}$. Asterisks indicate significant differences as compared to vehicle controls $\left(^{*}: p\right.$ $<0.05 ;{ }^{* *}: p<0.01 ; \mathrm{n}=3$ ). Error bars, SEM. small ( $140 \%$ of control), this early and long-lasting increase in BACE1 mRNA level was likely responsible for the elevation of BACE1 protein that we observed by immunoblot (Figure 7A, B). A substantial lag period existed between the increases of BACE1 mRNA and protein levels, most likely because the small BACE1 mRNA elevation resulted in a slow accumulation of BACE1 protein in astrocytes.

Thus far, our experiments demonstrated that $A \beta 42$ oligomers and fibrils could raise both endogenous APP and BACE1 levels in astrocytes. However, they did not address whether this elevation of substrate and enzyme could lead to greater $A \beta$ production. Unfortunately, we were unable to directly measure endogenous astrocytic $A \beta$ production in $A \beta 42$-treated astrocytes because the A $\beta 42$ treatment interfered with ELISA measurements of astrocytic $A \beta$ that was secreted into conditioned media (CM) (not shown). To overcome this problem, we designed an experiment to directly measure BACE1 processing of APP, which positively correlates with $\mathrm{A} \beta$ production in cells. In this experiment, we investigated the effects of $A \beta 42$ oligomers and fibrils on primary astrocytes cultured from Tg2576 transgenic mice that overexpress APPsw, which is a superior BACE1 substrate as compared to wild-type APP [52]. As a consequence, Tg2576 neurons and astrocytes exhibit rates of APPsw amyloidogenic processing and $A \beta$ production that are substantially higher than those of non-transgenic cells.

BACE1 cleavage of APPsw generates an N-terminal ectodomain fragment of APPsw that is named APPs $\beta$ sw. To measure levels of APPs $\beta$ sw, we generated an antibody that specifically recognizes the cleaved C-terminal neo-epitope of APPs $\beta$ sw following BACE1 processing [23]. We used this anti-APPs $\beta$ sw neo-epitope antibody to perform immunoblots of cell lysates from Tg2576 primary astrocytes that were stimulated with $\mathrm{A} \beta 42$ oligomers or fibrils for 24, 48, or $72 \mathrm{~h}$ (Figure 8). Tg2576 astrocytes expressed several fold more APP than nontransgenic astrocytes, demonstrating that the Tg2576 transgene promoter was active in astrocytes. Moreover, stimulation with $\mathrm{A} \beta 42$ oligomers and fibrils caused levels of both transgenic and endogenous APP to significantly increase in Tg2576 and non-transgenic astrocytes, respectively, at 24 and $48 \mathrm{~h}$ time-points (Figure 8 ), similar to results obtained with $\mathrm{A} \beta 42$-treated $\mathrm{C} 57 \mathrm{BL} / 6 \mathrm{~J}$ astrocytes (Figure 6). Most importantly, robust APPs $\beta$ sw signals on immunoblots indicated that $A \beta 42$ stimulation of $\operatorname{Tg} 2576$ astrocytes caused dramatic increases in BACE1 cleavage of APPsw at all treatment time-points. Both oligomeric and fibrillar A $\beta 42$ stimulation elevated APPs $\beta$ sw levels to similar extents at the earlier timepoints (Figure $8 \mathrm{~A}, \mathrm{~B}$ ), although the potency of $\mathrm{A} \beta 42$ oligomers appeared to decrease somewhat relative to $A \beta 42$ fibrils by $72 \mathrm{~h}$ of treatment (Figure $8 \mathrm{C}$ ). APPs $\beta$ sw signals 


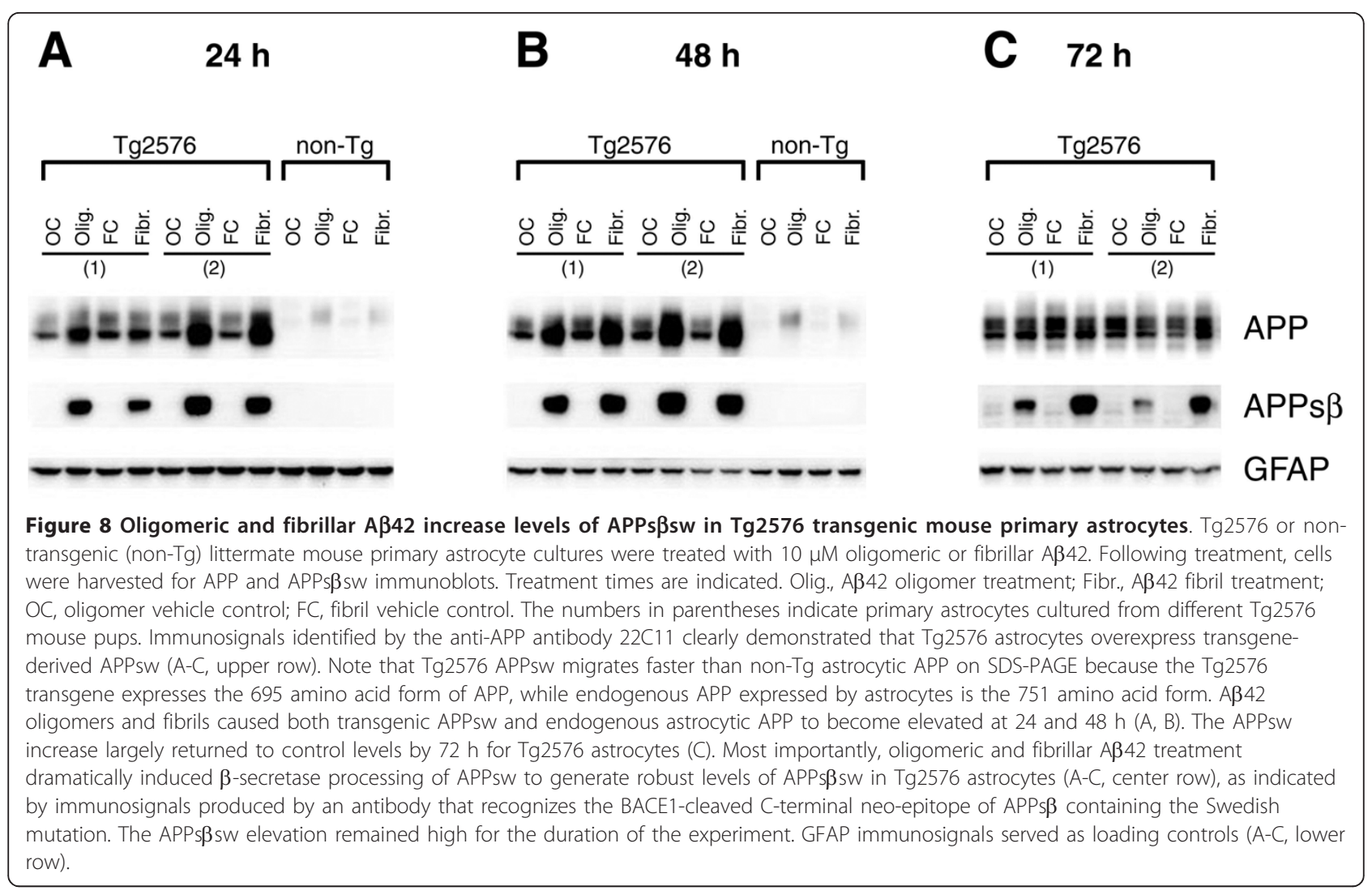

were absent in immunoblot lanes of lysates from vehicle control-treated Tg2576 astrocytes (Figure 8A-C), indicating that $\mathrm{A} \beta 42$ may have induced non-amyloidogenic astrocytes to initiate BACE1 cleavage of APP. Taken together, these results demonstrated that $A \beta 42$ oligomers and fibrils are not only capable of elevating levels of astrocytic APP and BACE1, but they could also increase BACE1 cleavage of APP in astrocytes, a prerequisite of $A \beta$ synthesis.

\section{Discussion}

Are astrocytes a significant source of $A \beta$ in $A D$ ? Is a feed-forward "vicious cycle" involved in AD pathogenesis? These are underappreciated yet critical questions that have important mechanistic and therapeutic implications for AD. Several studies have attempted to address certain aspects of these problems, but our study is the first to integrate these questions and address whether specific cytokine combinations and forms of A $\beta 42$ are capable of increasing amyloidogenic APP processing and $A \beta$ generation in astrocytes. We first determined that pro-inflammatory cytokine combinations including TNF- $\alpha+$ IFN $-\gamma$ synergistically increased levels of endogenous APP and BACE1 in astrocytes, as compared to individual cytokines alone. Following stimulation, astrocytic APP levels reached $\sim 300 \%$ of control at
$24 \mathrm{~h}$ and stayed relatively constant for the duration of the experiment (96 h). BACE1 levels, on the other hand, took longer to increase and gave no indication of leveling off by $96 \mathrm{~h}$ when they reached $\sim 400-600 \%$ of control. The cytokine combinations also caused significant increases of secreted $\mathrm{A} \beta 40$ levels, but this occurred only at $96 \mathrm{~h}$, demonstrating a significant lag period between increased levels of APP and BACE1 on the one hand and elevated $A \beta$ production and secretion on the other. Since levels of both $A \beta 40$ and $A \beta 42$ increase in parallel following BACE1 cleavage of APP [23], it is likely that astrocytic $A \beta 42$ production was also elevated by cytokine combinations including TNF- $\alpha+$ IFN- $\gamma$. Unexpectedly, IL- $1 \beta$ treatment resulted in a decrease of secreted A 340 levels at $96 \mathrm{~h}$. However, this may be understood in light of the observation that IL-1 $\beta$ treatment did not significantly increase astrocytic APP or BACE1 levels. Along with our results, other reports also indicate that IL- $1 \beta$ may reduce amyloidogenic processing of APP $[53,54]$. TNF- $\alpha+$ IFN- $\gamma$ stimulation was associated with robust elevations of APP, BACE1, and A $\beta$ in astrocytes. Interestingly, post-transcriptional mechanisms appeared to be responsible for a large proportion of the TNF- $\alpha$ + IFN $-\gamma$ stimulated increases in astrocytic APP and BACE1 levels. APP and BACE1 mRNA levels did not increase upon stimulation, with the exception of slightly 
elevated APP mRNA at $96 \mathrm{~h}$. In fact, BACE1 mRNA levels were significantly decreased by TNF- $\alpha+$ IFN- $\gamma$ stimulation, strongly suggesting that the BACE1 elevation was post-transcriptional.

Our study is also the first to show that both oligomeric and fibrillar forms of $A \beta 42$ increase the levels of astrocytic APP and BACE1 mRNA and protein, and that they stimulate $\beta$-secretase processing of APP in astrocytes. Similar to TNF- $\alpha+$ IFN- $\gamma$ stimulation, oligomeric and fibrillar $A \beta 42$ treatment of primary astrocytes elevated endogenous APP levels to $300-500 \%$ of control, although these increases were short-lived. Also, A 422 oligomers and fibrils caused robust, long-lived increases in astrocytic BACE1 levels ( $300 \%$ of control), akin to those caused by TNF- $\alpha+$ IFN- $\gamma$ stimulation. Although we were unable to directly measure $A \beta$ production in A $\beta 42$-stimulated astrocytes, we did interrogate $\beta$-secretase processing by analyzing the generation of APPs $\beta$ sw, the product of BACE1 cleavage, in A $\beta 42$-treated Tg2576 astrocytes. We found that $A \beta 42$ oligomers and fibrils strongly induced astrocytic BACE1 cleavage of APPsw. Given that $\beta$-secretase processing of APP and A $\beta$ production are tightly coupled, it is likely that $A \beta$ generation was also elevated in A $\beta 42$-stimulated Tg2576 astrocytes. Finally, the A $\beta 42$-stimulated elevations of astrocytic APP and BACE1 were potentially the result of increased APP and BACE1 gene transcription, at least in part. Although the APP increase was rapid but shortlived, the BACE1 elevation had a slower onset but was sustained for at least $96 \mathrm{~h}$ of $\mathrm{A} \beta 42$ stimulation.

The TNF- $\alpha+$ IFN- $\gamma$ - and A $\beta 42$-stimulated increases in astrocytic APP and BACE1 were remarkably similar, but some differences were also observed. For example, the APP and BACE1 elevations appeared to involve both transcriptional and post-transcriptional mechanisms, but to varying degrees depending on the stimulus. The TNF- $\alpha+$ IFN- $\gamma$ stimulated BACE1 increase was posttranscriptional, since BACE1 mRNA levels were reduced, while the $A \beta 42$-stimulated $B A C E 1$ increase involved BACE1 mRNA elevation. In addition, the early phases of the TNF- $\alpha+$ IFN- $\gamma$ stimulated astrocytic APP elevation did not involve increases in APP mRNA levels, suggesting a post-transcriptional mechanism, while the opposite was true for the A $\beta 42$-stimulated APP increase. Potential post-transcriptional mechanisms could involve enhanced translation or stability of APP and BACE1 mRNAs or proteins, as previously reported in other systems [55-57]. It remains to be determined whether these mechanisms or others could be responsible for the observed elevations of endogenous APP and BACE1 in astrocytes.

To gain insight into the signaling pathways responsible for the TNF- $\alpha+$ IFN- $\gamma$-stimulated increases in astrocytic APP, BACE1 and A $\beta$, we used inhibitors against two signaling molecules known to be involved in neuroinflammation, JAK and iNOS (Figure 9). Except for reducing APP levels with JAK inhibition, blocking neither JAK nor iNOS had a significant effect on astrocytic APP, BACE1, or secreted A 340 levels. However, our results do not necessarily mean that these molecules do not play important roles in cytokine-stimulated amyloidogenic APP processing in astrocytes, because the JAK and iNOS signaling cascades have complex regulation and they may adapt to inhibitor treatment $[58,59]$. Astrocytic effect sizes were largest with cytokine combinations, suggesting that activation of multiple signaling pathways summed together in a synergistic fashion to elevate astrocytic APP, BACE1, and A $\beta$. Further work using multiple inhibitors or genetic knockdown approaches will be necessary to dissect precisely which signaling molecules are the most critical for cytokine-stimulated elevations of APP, BACE1, and A $\beta$ in astrocytes.

We did not directly address the molecular mechanisms by which $\mathrm{A} \beta 42$ raised the levels of APP, BACE1, and $\beta$-secretase processing in astrocytes. However, the higher levels of astrocytic APP and BACE1 mRNA that we observed following $A \beta 42$ stimulation suggested increased gene transcription was responsible, at least in part. Little is known about the regulation of APP and BACE1 gene expression in astrocytes. A recent study has suggested that NF- $\kappa \mathrm{B}$ may activate the BACE1 gene promoter in TNF- $\alpha$-stimulated astrocytes [51]. In addition, IFN- $\gamma$ may activate the BACE1 gene promoter in astrocytes via the JAK/STAT pathway [39]. However, in our study, JAK inhibition did not block the TNF- $\alpha$ + IFN- $\gamma$-stimulated increase in astrocytic BACE1, and BACE1 mRNA levels were actually reduced with TNF- $\alpha$

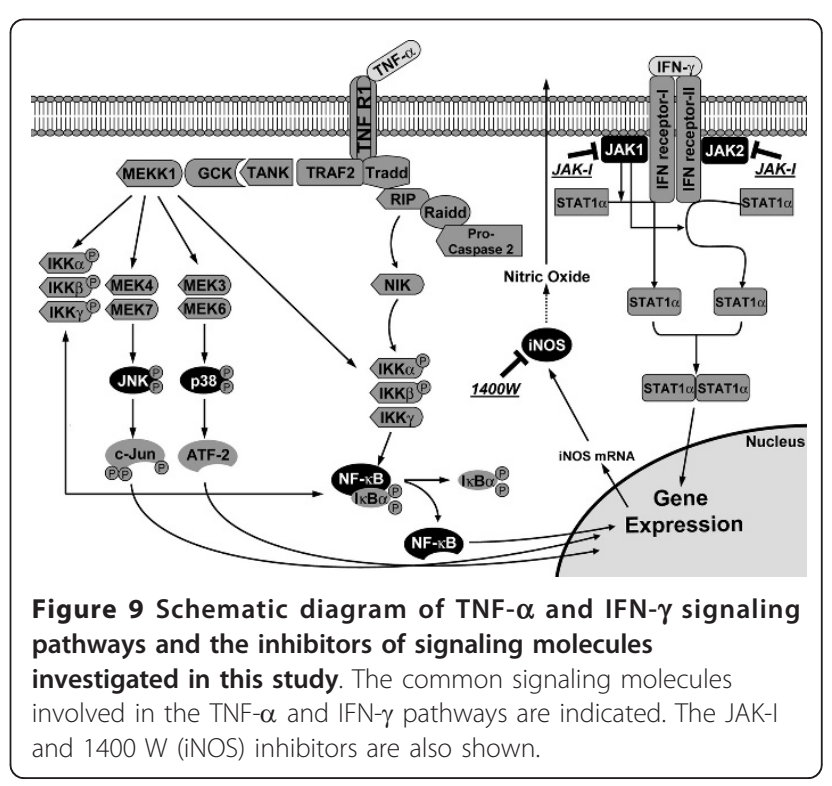


+ IFN- $\gamma$. The reason of this discrepancy is unknown. Clearly, further work is necessary to resolve this issue in the future.

Far less is known about APP gene regulation in astrocytes. TGF $\beta$ appears to increase APP gene transcription in astrocytes, but few other cytokines have been investigated. Regulation of astrocytic APP and BACE1 levels may be complex, since additional evidence exists that pro-inflammatory cytokines may also control the translation of APP and BACE1 mRNA in astrocytes $[55,60]$. Importantly, except for our work, none of these studies directly addressed whether $A \beta 42$ oligomers or fibrils could increase astrocytic APP or BACE1 mRNA levels.

BACE1 levels in astrocytes are normally very low compared to neurons $[23,28]$. However, our results have shown that astrocytic BACE1 levels can be strongly induced to $\sim 300-600 \%$ over control levels when astrocytes are stimulated by cytokine combinations or $A \beta 42$. Moreover, astrocytic APP levels are also increased several fold by cytokine and $A \beta 42$ stimulation. Together, these effects result in significantly elevated $\beta$-secretase processing of APP and A $\beta$ generation in stimulated, as compared to un-stimulated, astrocytes. It has not yet been rigorously determined whether stimulated astrocytes produce similar levels of $A \beta$ as neurons on a per cell basis, but this seems unlikely. However, because astrocytes greatly outnumber neurons, even a relatively small increase in astrocytic $A \beta$ generation may make a significant contribution to the total $A \beta$ burden in the AD brain.

Our study also suggests that a feed-forward mechanism in AD may operate to elevate and sustain astrocytic amyloidogenic APP processing. This feed-forward mechanism may involve the following steps: 1 . Proinflammatory cytokines including TNF- $\alpha$ and IFN- $\gamma$ stimulate astrocytes to increase levels of BACE1, APP, and secreted $A \beta ; 2$. As cerebral $A \beta$ levels rise, $A \beta 42$ oligomers and fibrils begin to form; 3 . Both oligomeric and fibrillar $A \beta 42$ induce and/or sustain high levels of astrocytic BACE1, APP, and $\beta$-secretase processing; 4 . Cerebral $A \beta$ levels are further elevated, promoting greater cytokine and $A \beta$ production, thus creating a vicious cycle. Evidence in favor this hypothesis exists, in that $\mathrm{A} \beta 42$ is capable of stimulating astrocytes to secrete proinflammatory cytokines, and conversely cytokine combinations that include TNF- $\alpha$ and IFN- $\gamma$ increase astrocytic $A \beta$ synthesis, together forming the elements of a feed-forward loop [35,42-45]. In addition, it is important to note that the BACE1-cleaved ectodomain of APP, APPs $\beta$, is capable of activating microglia [61]. Moreover, $\mathrm{A} \beta$ itself can cause microglial activation [3,17]. Thus, microglia are likely to participate in the astrocytic feedforward mechanism as part of a larger cytokine cycle of neuroinflammation $[4,17]$. Finally, the trigger of the astrocytic feed-forward loop is unclear, although agerelated deficits in $A \beta$ clearance mechanisms may cause an initial rise in cerebral $A \beta$ level that could start the vicious cycle $[62,63]$. Such an astrocytic feed-forward mechanism could have important implications for both pathogenesis and therapeutic strategies for $\mathrm{AD}$.

\section{Conclusions}

In summary, we demonstrate here that cytokine combinations including TNF- $\alpha$ and IFN- $\gamma$, as well as A $\beta 42$ oligomers and fibrils, increase levels of BACE1, APP, and $\beta$ secretase processing in cultured primary astrocytes, and that these effects can lead to increased astrocytic $A \beta$ secretion, at least in the case of TNF- $\alpha+$ IFN- $\gamma$ stimulation. Given that astrocytes are much more numerous than neurons in the brain, our results present strong evidence that activated astrocytes may make a significant contribution to total $\mathrm{A} \beta$ burden in $\mathrm{AD}$ under neuroinflammatory conditions. Moreover, our data suggest a potential feed-forward vicious cycle of astrocytic activation and $A \beta$ generation. Overall, our results have important pathogenic and therapeutic implications for $\mathrm{AD}$.

\section{List of abbreviations}

A $\boldsymbol{\beta}$ : Amyloid- $\beta$; AD: Alzheimer's disease; APP: amyloid precursor protein; BACE1: $\beta$-site APP-cleaving enzyme 1; BSA: bovine serum albumin; CM: conditioned media; CNS: central nervous system; DMEM: Dulbecco's modified Eagle's medium; DMSO: Dimethyl sulfoxide; D-PBS: Dulbecco's phosphate-buffered saline; EDTA: ethylenediamine tetra-acetic acid; ELISA: enzyme-linked immunosorbant assay; FBS: fetal bovine serum; GFAP: glial fibrillary acidic protein; IFN- $\gamma$ : interferon- $\gamma$; IL-1 $\beta$ : interleukin-1 $\beta$; iNOS: inducible nitric oxide synthases; JAK: Janus kinase; LPS: Iypopolysaccharide; PVDF: polyvinylidene difluoride; RT: room temperature; SDS: sodium dodecyl sulfate; TNF-a: tumor necrosis factor-a.

\section{Acknowledgements}

The authors thank Holly Oakley and Erika Maus for their dedicated support in maintaining the mouse colony for the mouse astrocyte cultures. We thank Dr. Mary Jo LaDu and her lab for providing the prepared lyophilized Aß42 peptide, and Dr. Linda Van Eldik and her lab for training and advice on primary astrocyte culture and for assistance with preparation of $A \beta 42$ oligomers and fibrils. We are also grateful to Dr. Alfred Rademaker for his excellent statistical advice and Dr. Linda Van Eldik for her careful review of earlier versions of the manuscript. This work was supported by funding from the National Institute of Aging (P01 AG021184 and R01 AG030142).

\section{Authors' contributions}

JZ, TO performed the experiments. JZ, RV conceived of and designed the experimental plan and wrote the manuscript. All authors have read and approved the final version of the manuscript.

\section{Competing interests}

The authors declare that they have no competing interests.

Received: 26 August 2011 Accepted: 2 November 2011

Published: 2 November 2011

\section{References}

1. Holtzman DM, Morris JC, Goate AM: Alzheimer's disease: the challenge of the second century. Sci Transl Med 2011, 3:77sr1.

2. De Strooper B: Proteases and proteolysis in Alzheimer disease: a multifactorial view on the disease process. Physiol Rev 2010, 90:465-94. 
3. Heneka MT, O'Banion MK, Terwel D, Kummer MP: Neuroinflammatory processes in Alzheimer's disease. J Neural Transm 2010, 117:919-47.

4. Mrak RE, Griffin WS: Glia and their cytokines in progression of neurodegeneration. Neurobiol Aging 2005, 26:349-54.

5. Sastre M, Walter J, Gentleman SM: Interactions between APP secretases and inflammatory mediators. J Neuroinflammation 2008, 5:25.

6. Griffin WS, Stanley LC, Ling C, White L, MacLeod V, Perrot L, White CL, Araoz C: Brain interleukin 1 and S-100 immunoreactivity are elevated in Down syndrome and Alzheimer disease. Proc Natl Acad Sci USA 1989, 86:7611-7615

7. Griffin WS, Sheng JG, Roberts GW, Mrak RE: Interleukin-1 expression in different plaque types in Alzheimer's disease: significance in plaque evolution. J Neuropathol Exp Neurol 1995, 54:276-281.

8. Dandrea MR, Reiser PA, Gumula NA, Hertzog BM, Andrade-Gordon P: Application of triple immunohistochemistry to characterize amyloid plaque-associated inflammation in brains with Alzheimer's disease. Biotech Histochem 2001, 76:97-106.

9. Maat-Schieman ML, Rozemuller AJ, van Duinen SG, Haan J, Eikelenboom P, Roos RA: Microglia in diffuse plaques in hereditary cerebral hemorrhage with amyloidosis (Dutch). An immunohistochemical study. J Neuropathol Exp Neurol 1994, 53:483-491.

10. Van Eldik LJ, Griffin WS: S100 beta expression in Alzheimer's disease: relation to neuropathology in brain regions. Biochim Biophys Acta 1994, 1223:398-403.

11. Benzing WC, Wujek JR, Ward EK, Shaffer D, Ashe KH, Younkin SG, Brunden KR: Evidence for glial-mediated inflammation in aged APP(SW) transgenic mice. Neurobiol Aging 1999, 20:581-9.

12. Matsuoka Y, Picciano M, Malester B, LaFrancois J, Zehr C, Daeschner JM, Olschowka JA, Fonseca MI, O'Banion MK, Tenner AJ, Lemere CA, Duff K: Inflammatory responses to amyloidosis in a transgenic mouse model of Alzheimer's disease. Am J Pathol 2001, 158:1345-54.

13. Bornemann KD, Wiederhold KH, Pauli C, Ermini F, Stalder M, Schnell L, Sommer B, Jucker M, Staufenbiel M: Abeta-induced inflammatory processes in microglia cells of APP23 transgenic mice. Am J Pathol 2001, 158:63-73

14. Dudal S, Krzywkowski P, Paquette J, Morissette C, Lacombe D, Tremblay P, Gervais F: Inflammation occurs early during the Abeta deposition process in TgCRND8 mice. Neurobiol Aging 2004, 25:861-71.

15. Gärtner U, Brückner MK, Krug S, Schmetsdorf S, Staufenbiel M, Arendt T: Amyloid deposition in APP23 mice is associated with the expression of cyclins in astrocytes but not in neurons. Acta Neuropathol 2003, 106:535-44.

16. Terai K, Iwai A, Kawabata S, Sasamata M, Miyata K, Yamaguchi T: Apolipoprotein $E$ deposition and astrogliosis are associated with maturation of beta-amyloid plaques in betaAPPswe transgenic mouse: Implications for the pathogenesis of Alzheimer's disease. Brain Res 2001 900:48-56.

17. Akiyama H, Barger S, Barnum S, Bradt B, Bauer J, Cole GM, Cooper NR, Eikelenboom P, Emmerling M, Fiebich BL, Finch CE, Frautschy S, Griffin WS, Hampel H, Hull M, Landreth G, Lue L, Mrak R, Mackenzie IR, McGeer PL, O'Banion MK, Pachter J, Pasinetti G, Plata-Salaman C, Rogers J, Rydel R, Shen Y, Streit W, Strohmeyer R, Tooyoma I, et al: Inflammation and Alzheimer's disease. Neurobiol Aging 2000, 21:383-421.

18. Griffin WS, Sheng JG, Royston MC, Gentleman SM, McKenzie JE, Graham DI, Roberts GW, Mrak RE: Glial-neuronal interactions in Alzheimer's disease: the potential role of a 'cytokine cycle' in disease progression. Brain Pathol 1998, 8:65-72.

19. Frank-Cannon TC, Alto LT, McAlpine FE, Tansey MG: Does neuroinflammation fan the flame in neurodegenerative diseases? Mol Neurodegener 2009, 4:47

20. McGeer PL, McGeer EG: The inflammatory response system of brain: implications for therapy of Alzheimer and other neurodegenerative diseases. Brain Res Brain Res Rev 1995, 21:195-218.

21. Zhao J, Paganini L, Mucke L, Gordon M, Refolo L, Carman M, Sinha S, Oltersdorf T, Lieberburg I, McConlogue L: Beta-secretase processing of the beta-amyloid precursor protein in transgenic mice is efficient in neurons but inefficient in astrocytes. J Biol Chem 1996, 271:31407-11.

22. Calhoun $M E$, Burgermeister $P$, Phinney $A L$, Stalder $M$, Tolnay $M$ Wiederhold KH, Abramowski D, Sturchler-Pierrat C, Sommer B, Staufenbiel M, Jucker M: Neuronal overexpression of mutant amyloid precursor protein results in prominent deposition of cerebrovascular amyloid. Proc Natl Acad Sci USA 1999, 96:14088-93.

23. Vassar R, Bennett BD, Babu-Khan S, Kahn S, Mendiaz EA, Denis P, Teplow DB, Ross S, Amarante P, Loeloff R, Luo Y, Fisher S, Fuller J, Edenson S, Lile J, Jarosinski MA, Biere AL, Curran E, Burgess T, Louis JC, Collins F, Treanor J, Rogers G, Citron M: Beta-secretase cleavage of Alzheimer's amyloid precursor protein by the transmembrane aspartic protease BACE. Science 1999, 286:735-41.

24. Yan R, Bienkowski MJ, Shuck ME, Miao H, Tory MC, Pauley AM, Brashier JR, Stratman NC, Mathews WR, Buhl AE, Carter DB, Tomasselli AG, Parodi LA Heinrikson RL, Gurney ME: Membrane-anchored aspartyl protease with Alzheimer's disease beta-secretase activity. Nature 1999, 402:533-7.

25. Sinha S, Anderson JP, Barbour R, Basi GS, Caccavello R, Davis D, Doan M, Dovey HF, Frigon N, Hong J, Jacobson-Croak K, Jewett N, Keim P, Knops J, Lieberburg I, Power M, Tan H, Tatsuno G, Tung J, Schenk D, Seubert P Suomensaari SM, Wang S, Walker D, Zhao J, McConlogue L, John V: Purification and cloning of amyloid precursor protein beta-secretase from human brain. Nature 1999, 402:537-40.

26. Hussain I, Powell D, Howlett DR, Tew DG, Meek TD, Chapman C, Gloger IS, Murphy KE, Southan CD, Ryan DM, Smith TS, Simmons DL, Walsh FS, Dingwall C, Christie G: Identification of a novel aspartic protease (Asp 2) as beta-secretase. Mol Cell Neurosci 1999, 14:419-27.

27. Lin X, Koelsch G, Wu S, Downs D, Dashti A, Tang J: Human aspartic protease memapsin 2 cleaves the beta-secretase site of beta-amyloid precursor protein. Proc Natl Acad Sci USA 2000, 97:1456-60.

28. Laird FM, Cai H, Savonenko AV, Farah MH, He K, Melnikova T, Wen H, Chiang HC, Xu G, Koliatsos VE, Borchelt DR, Price DL, Lee HK, Wong PC: BACE1, a major determinant of selective vulnerability of the brain to amyloid-beta amyloidogenesis, is essential for cognitive, emotional, and synaptic functions. J Neurosci 2005, 25:11693-709.

29. Sofroniew MV, Vinters HV: Astrocytes: biology and pathology. Acto Neuropathol 2010, 119:7-35.

30. Kandel ER, Schwartz JH, Jessell TM: Principles of Neural Science. 4 edition. New York: McGraw-Hill Medical Press; 2000.

31. Brugg B, Dubreuil YL, Huber G, Wollman EE, Delhaye-Bouchaud N, Mariani J: Inflammatory processes induce beta-amyloid precursor protein changes in mouse brain. Proc Natl Acad Sci USA 1995, 92:3032-5.

32. Sheng JG, Bora SH, Xu G, Borchelt DR, Price DL, Koliatsos VE: Lipopolysaccharide-induced-neuroinflammation increases intracellular accumulation of amyloid precursor protein and amyloid beta peptide in APPswe transgenic mice. Neurobiol Dis 2003, 14:133-45.

33. Blasko I, Marx F, Steiner E, Hartmann T, Grubeck-Loebenstein B: TNFalpha plus IFNgamma induce the production of Alzheimer beta-amyloid peptides and decrease the secretion of APPS. FASEB J 1999, 13:63-8

34. Rogers JT, Leiter LM, McPhee J, Cahill CM, Zhan SS, Potter H, Nilsson LN: Translation of the alzheimer amyloid precursor protein mRNA is upregulated by interleukin- 1 through $5^{\prime}$-untranslated region sequences. $J$ Biol Chem 1999, 274:6421-31.

35. Blasko I, Veerhuis R, Stampfer-Kountchev M, Saurwein-Teissl M, Eikelenboom P, Grubeck-Loebenstein B: Costimulatory effects of interferon-gamma and interleukin-1beta or tumor necrosis factor alpha on the synthesis of Abeta1-40 and Abeta1-42 by human astrocytes. Neurobiol Dis 2000, 7:682-9.

36. Sastre M, Dewachter I, Landreth GE, Willson TM, Klockgether T, van Leuven F, Heneka MT: Nonsteroidal anti-inflammatory drugs and peroxisome proliferator-activated receptor-gamma agonists modulate immunostimulated processing of amyloid precursor protein through regulation of beta-secretase. J Neurosci 2003, 23:9796-804

37. Hsiao K, Chapman P, Nilsen S, Eckman C, Harigaya Y, Younkin S, Yang F, Cole G: Correlative memory deficits, Abeta elevation, and amyloid plaques in transgenic mice. Science 1996, 274:99-102.

38. Hong HS, Hwang EM, Sim HJ, Cho HJ, Boo JH, Oh SS, Kim SU, Mook-Jung I: Interferon gamma stimulates beta-secretase expression and sAPPbeta production in astrocytes. Biochem Biophys Res Commun 2003, 307:922-7.

39. Cho HJ, Kim SK, Jin SM, Hwang EM, Kim YS, Huh K, Mook-Jung I: IFNgamma-induced BACE1 expression is mediated by activation of JAK2 and ERK1/2 signaling pathways and direct binding of STAT1 to BACE1 promoter in astrocytes. Glia 2007, 55:253-62.

40. Yamamoto M, Kiyota T, Horiba M, Buescher JL, Walsh SM, Gendelman HE, Ikezu T: Interferon-gamma and tumor necrosis factor-alpha regulate 
amyloid-beta plaque deposition and beta-secretase expression in Swedish mutant APP transgenic mice. Am J Pathol 2007, 170:680-92.

41. He P, Zhong Z, Lindholm K, Berning L, Lee W, Lemere C, Staufenbiel M, $L i R$, Shen Y: Deletion of tumor necrosis factor death receptor inhibits amyloid beta generation and prevents learning and memory deficits in Alzheimer's mice. J Cell Biol 2007, 178:829-41.

42. Hu J, Akama KT, Krafft GA, Chromy BA, Van Eldik LJ: Amyloid-beta peptide activates cultured astrocytes: morphological alterations, cytokine induction and nitric oxide release. Brain Res 1998, 785:195-206.

43. White JA, Manelli AM, Holmberg KH, Van Eldik L, Ladu MJ: Differential effects of oligomeric and fibrillar amyloid-beta 1-42 on astrocytemediated inflammation. Neurobiol Dis 2005, 18:459-65.

44. Akama KT, Van Eldik LJ: Beta-amyloid stimulation of inducible nitric-oxide synthase in astrocytes is interleukin-1 beta- and tumor necrosis factoralpha (TNFalpha)-dependent, and involves a TNFalpha receptorassociated factor- and NFkappaB-inducing kinase-dependent signaling mechanism. J Biol Chem 2000, 275:7918-24.

45. Craft JM, Watterson DM, Frautschy SA, Van Eldik LJ: Aminopyridazines inhibit beta-amyloid-induced glial activation and neuronal damage in vivo. Neurobiol Aging 2004, 25:1283-92.

46. Nimmrich V, Ebert U: Is Alzheimer's disease a result of presynaptic failure? Synaptic dysfunctions induced by oligomeric beta-amyloid. Rev Neurosci 2009, 20:1-12.

47. Hu J, Castets F, Guevara JL, Van Eldik L: S100 beta stimulates inducible nitric oxide synthase activity and mRNA levels in rat cortical astrocytes. $J$ Biol Chem 1996, 271:2543-7.

48. Stine $W B$, Jungbauer $L, Y u C$, LaDu MJ: Preparing synthetic $A \beta$ in different aggregation states. Methods Mol Biol 2011, 670:13-32.

49. Velliquette RA, O'Connor T, Vassar R: Energy inhibition elevates betasecretase levels and activity and is potentially amyloidogenic in APP transgenic mice: possible early events in Alzheimer's disease pathogenesis. J Neurosci 2005, 25:10874-83.

50. Luo Y, Bolon B, Kahn S, Bennett BD, Babu-Khan S, Denis P, Fan W, Kha H, Zhang J, Gong Y, Martin L, Louis JC, Yan Q, Richards WG, Citron M, Vassar R: Mice deficient in BACE1, the Alzheimer's beta-secretase, have normal phenotype and abolished beta-amyloid generation. Nat Neurosci 2001 4:231-2.

51. Bourne KZ, Ferrari DC, Lange-Dohna C, Rossner S, Wood TG, Perez-Polo JR: Differential regulation of BACE1 promoter activity by nuclear factorkappaB in neurons and glia upon exposure to beta-amyloid peptides. J Neurosci Res 2007, 85:1194-204.

52. Citron M, Oltersdorf T, Haass C, McConlogue L, Hung AY, Seubert P, VigoPelfrey C, Lieberburg I, Selkoe DJ: Mutation of the beta-amyloid precursor protein in familial Alzheimer's disease increases beta-protein production. Nature 1992, 360:672-4

53. Tachida Y, Nakagawa K, Saito T, Saido TC, Honda T, Saito Y, Murayama S, Endo T, Sakaguchi G, Kato A, Kitazume S, Hashimoto Y: Interleukin-1 beta up-regulates TACE to enhance alpha-cleavage of APP in neurons: resulting decrease in Abeta production. J Neurochem 2008, 104:1387-93.

54. Shaftel SS, Kyrkanides S, Olschowka JA, Miller JN, Johnson RE, O'Banion MK: Sustained hippocampal IL-1 beta overexpression mediates chronic neuroinflammation and ameliorates Alzheimer plaque pathology. J Clin Invest 2007, 117:1595-604.

55. Rogers JT, Leiter LM, McPhee J, Cahill CM, Zhan SS, Potter H, Nilsson LN: Translation of the alzheimer amyloid precursor protein mRNA is upregulated by interleukin-1 through 5 '-untranslated region sequences. J Biol Chem 1999, 274:6421-31.

56. Tesco G, Koh YH, Kang EL, Cameron AN, Das S, Sena-Esteves M, Hiltunen M, Yang SH, Zhong Z, Shen Y, Simpkins JW, Tanzi RE: Depletion of GGA3 stabilizes BACE and enhances beta-secretase activity. Neuron 2007, 54:721-37.

57. O'Connor T, Sadleir KR, Maus E, Velliquette RA, Zhao J, Cole SL, Eimer WA, Hitt B, Bembinster LA, Lammich S, Lichtenthaler SF, Hébert SS, De Strooper B, Haass C, Bennett DA, Vassar R: Phosphorylation of the translation initiation factor elF2alpha increases BACE1 levels and promotes amyloidogenesis. Neuron 2008, 60:988-1009.

58. Wu Y, Zhou BP: TNF-alpha/NF-kappaB/Snail pathway in cancer cell migration and invasion. Br J Cancer 2010, 102:639-44.

59. Saha B, Jyothi Prasanna S, Chandrasekar B, Nandi D: Gene modulation and immunoregulatory roles of interferon gamma. Cytokine 2010, 50:1-14.
60. Bettegazzi B, Mihailovich M, Di Cesare A, Consonni A, Macco R, Pelizzoni I, Codazzi F, Grohovaz F, Zacchetti D: $\beta$-Secretase activity in rat astrocytes: translational block of BACE1 and modulation of BACE2 expression. Eur J Neurosci 2011, 33:236-43.

61. Barger SW, Harmon AD: Microglial activation by Alzheimer amyloid precursor protein and modulation by apolipoprotein E. Nature 1997, 388:878-81.

62. Mawuenyega KG, Sigurdson W, Ovod V, Munsell L, Kasten T, Morris JC, Yarasheski KE, Bateman RJ: Decreased clearance of CNS beta-amyloid in Alzheimer's disease. Science 2010, 330:1774

63. Castellano JM, Kim J, Stewart FR, Jiang H, Demattos RB, Patterson BW, Fagan AM, Morris JC, Mawuenyega KG, Cruchaga C, Goate AM, Bales KR, Paul SM, Bateman RJ, Holtzman DM: Human apoE Isoforms Differentially Regulate Brain Amyloid-beta Peptide Clearance. Sci Transl Med 2011, 3:89ra57.

doi:10.1186/1742-2094-8-150

Cite this article as: Zhao et al: The contribution of activated astrocytes to $A \beta$ production: Implications for Alzheimer's disease pathogenesis. Journal of Neuroinflammation 2011 8:150.

\section{Submit your next manuscript to BioMed Central and take full advantage of:}

- Convenient online submission

- Thorough peer review

- No space constraints or color figure charges

- Immediate publication on acceptance

- Inclusion in PubMed, CAS, Scopus and Google Scholar

- Research which is freely available for redistribution

Submit your manuscript at www.biomedcentral.com/submit
C Biomed Central 